\title{
Archaeological investigations at Waredaru and the origins of the Keipte Kuyumen clan estate, upper Kikori River, Papua New Guinea
}

Investigations archéologiques à Waredaru et origines du Clan Keipte Kuyumen, upper Kikori River, Papouasie Nouvelle-Guinée

Bruno David, Jérôme Mialanes, Fiona Petchey, Ken Aplin, Jean-Michel Geneste, Robert Skelly and Cassandra Rowe

\section{OpenEdition}

\section{Journals}

\section{Electronic version}

URL: http://journals.openedition.org/paleo/2890

DOI: $10.4000 /$ paleo.2890

ISSN: 2101-0420

\section{Publisher}

SAMRA

\section{Printed version}

Date of publication: 1 December 2015

Number of pages: $33-57$

ISSN: $1145-3370$

Electronic reference

Bruno David, Jérôme Mialanes, Fiona Petchey, Ken Aplin, Jean-Michel Geneste, Robert Skelly and Cassandra Rowe, «Archaeological investigations at Waredaru and the origins of the Keipte Kuyumen clan estate, upper Kikori River, Papua New Guinea », PALEO [Online], 26 | 2015, Online since 26 April 2016, connection on 07 July 2020. URL : http://journals.openedition.org/paleo/2890 ; DOI : https:// doi.org/10.4000/paleo.2890

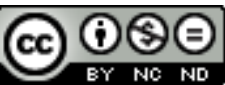

PALEO est mis à disposition selon les termes de la licence Creative Commons Attribution - Pas d'Utilisation Commerciale - Pas de Modification 4.0 International. 


\title{
Archaeological investigations at Waredaru and the origins of the Keipte Kuyumen clan estate, upper Kikori River, Papua New Guinea
}

\author{
Bruno DAVID(a), Jérôme MIALANES(a), Fiona PETCHEY'(b), \\ Ken APLIN ${ }^{(c)}$, Jean-Michel GENESTE ${ }^{(d)}$, Robert SKELLY(a), \\ Cassandra ROWE(a)
}

\begin{abstract}
In 2008-2009, the patriarch of the Keipte Kuyumen clan of the upper Kikori River near the Highlands foothills, Papua New Guinea, requested that archaeological excavations be undertaken at the site of Waredaru in a dense rainforest setting, an ancestral village only known from oral traditions. According to these oral traditions, Waredaru was a sago adze-head ('sago-pounder') manufacturing centre, and it is at this village that the Keipte Kuyumen underwent an important ceremony by which they obtained their clan lands. This paper reports on these archaeological excavations, enabling the rare dating of the origins of the Keipte Kuyumen as a landed social group.

Key-words: Papua New Guinea, Keipte Kuyumen clan, Archaeology, Oral traditions, Kikori River, Ethnoarchaeology.

Résumé : Investigations archéologiques à Waredaru et origines du Clan Keipte Kuyumen, upper Kikori River, Papouasie NouvelleGuinée. En 2008-2009, le patriarche du clan Keipte Kuyumen localisé en amont de la rivière Kikori, près des contreforts des Hautes Terres de Papouasie-Nouvelle-Guinée, a demandé la réalisation de fouilles archéologiques sur le site de Waredaru, un village ancestral seulement connu des traditions orales, situé au milieu d'une forêt dense tropicale. Selon ces traditions orales, Waredaru était un centre de fabrication de têtes d'herminettes à sagou en silex, et c'est aussi dans ce village que se déroulaient d'importantes cérémonies par lesquelles les membres du clan Keipte Kuyumen obtenaient leurs terres claniques. Cet article présente les résultats de ces fouilles archéologiques qui ont permis - fait rare - d'attester de l'ancienneté de l'origine de l'occupation par les Keipte Kuyumen de leur territoire clanique.
\end{abstract}

Mots-clés : Papouasie Nouvelle Guinée, clan Keipte Kuyumen, archéologie, traditions orales, rivière Kikori, ethnoarchéologie.

(a) Monash Indigenous Centre, Monash University, Clayton, Victoria 3800, Australia. bruno.david@monash.edu; jerome.mialanes@monash.edu; robert.skelly@monash.edu; cassandra.rowe@monash.edu

(b) Radiocarbon Dating Laboratory, University of Waikato, Hamilton 3240, New Zealand. fpetchey@ waikato.ac.nz

(c) Division of Mammals, National Museum of Natural History, Smithsonian Institution, Washington D.C. 20013-7012,

U.S.A. aplink@si.edu

(d) UMR PACEA 5199 CNRS, Université de Bordeaux, France ; La Mouthe basse, FR-24620 Les Eyzies -

jeanmichelgeneste@orange.fr 


\section{Introduction}

Understanding the historical emergence of social arrangements such as individual tribes, clans or lineages is one of archaeology's greatest challenges, due to the immateriality of such social constructs. Sometimes, however, social structures leave material traces that can be archaeologically tracked, such as in the association of a particular ethnographic social institution with particular forms of infrastructure (e.g. Umberger 2002), or the formalised movement of goods emanating from centralised places relating to those particular groups or institutions (e.g. Irwin 1985). Here we report a rare archaeological tracking of the origin of an ethnographic clan estate from the upper Kikori River, Gulf Province, Papua New Guinea.

\section{The Keipte Kuyumen}

The people of the Baina area of the upper Kikori River trace their ultimate origins to Mt Bosavi some $100 \mathrm{~km}$ to the northwest of their present homelands, their (usually named) mythical ancestors eventually settling in their current clan estates (fig. 1, 2). In due course, ancestral Kuyumen clan members went to Kupure, some three to four days' walk inland of Keip Creek, a tributary of the upper Kikori River. During the course of their ancestral migrations and the inhabitation of locations along the way and at their final destinations, the Keipte Kuyumen and other nearby clans encountered special beings, some with sacred names in some cases too powerful to be mentioned within hearing of small children or the weak such as Digira, a light-skinned woman with particular powers; or Kotoparo, a sacred woman who travelled westward; or Sagiribu, a sacred woman who went towards the Highlands (Wero Sisira, Keipte Kuyumen clan, personal communication 2009). The Keipte Kuyumen share historical ties with other clans including Kam Kuyumen (whose neighbouring lands are further inland of Keip Creek in the more elevated 'stone country' (kam means 'stone')) who trace back common ancestral roots and which together formed the original Kuyumen clan, as retold in present-day local oral traditions. Today Keipte Kuyumen territory also neighbours Kapakapa and Peremen clan territories to the south; from a place called Memeti going inland it then shares territorial boundaries with the Kuyumen Diban clan; from an area between Obosu (Kuyumen Diban clan) and Kikos (Kesele clan) it then shares territorial boundaries with the Kesele clan on the south side of Keip Creek, to a small creek called Kikirihabo on the north side; after Kikirihabo, the Keipte Kuyumen share territorial boundaries with the Mukul Diban clan from a place called Sisimkusobre (another small creek) (fig. 2).

In February 2009, BD and RS were taken to Waredaru, the location of an important ancestral Keipte Kuyumen clan village at the heart of their clan lands. Keipte Kuyumen clan elders Wero Sisira, Mauke Omare and the late Kuto Sisira wished to document this site known from oral histories for future generations, and thereby asked

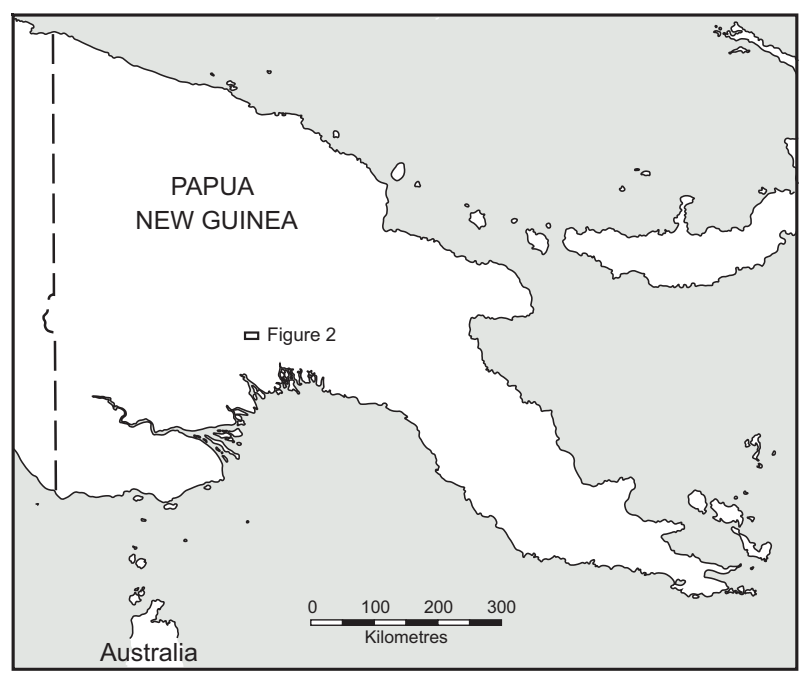

Figure 1 - Location of study area.

Figure 1 - Localisation de la zone d'étude.

us to undertake archaeological excavations. Wero Sisira, the Keipte Kuyumen patriarch, recounted to BD, RS and clan members at the present clan village base of Karupai, that the village of Waredaru did not exist during colonial times (the period from the 1870 s to Independence) when the first patrol officers came through the area, as the ancestral village had already long-ceased to be used before the first patrol officers entered Keipte Kuyumen lands. At a number of locations Wero Sisira told various aspects of the Keipte Kuyumen clan story in the local Keipte language (as Keipte Kuyumen clan members name the language; linguists recognise it variously as Ikobi Kairi, Ikobi-Mena or Kasere), with his brother's son Michael Mauke translating to English:

"Once upon a time there lived Kuyumen people. At the village of Waredaru the clan leader was called Boro, while at the contemporaneous village of Amisago it was his brother Weiave. One day, Weiave went hunting with his dogs. While walking, he saw footprints of a wild pig in the ground. He followed the pig's footprints. Later on he came across a swamp called Doubo (Grid Reference: 54M UTM 0790159 9233509, AGD66). In that swamp, the pig's footprints disappeared. Weiave started looking around at Doubo, and he said "Oh, this is a place for planting my sago". So he collected some sago suckers and planted them in the swamp, and then returned to where he had come. The next day Weiave came back to check the sago he'd planted the day before, to find that someone had chopped it down.

At Papatiti, where the Kesele people live now, a woman called Sagasibu lived. One day, Sagasibu went to where the Kuyumen people lived. She talked to the people, asking who planted the sago suckers in the swamp. The people said: "It might be Weiave, because Weiave usually hunts in that area". Sagasibu and her two brothers Haiba and Sawa thus told Weiave's people to 


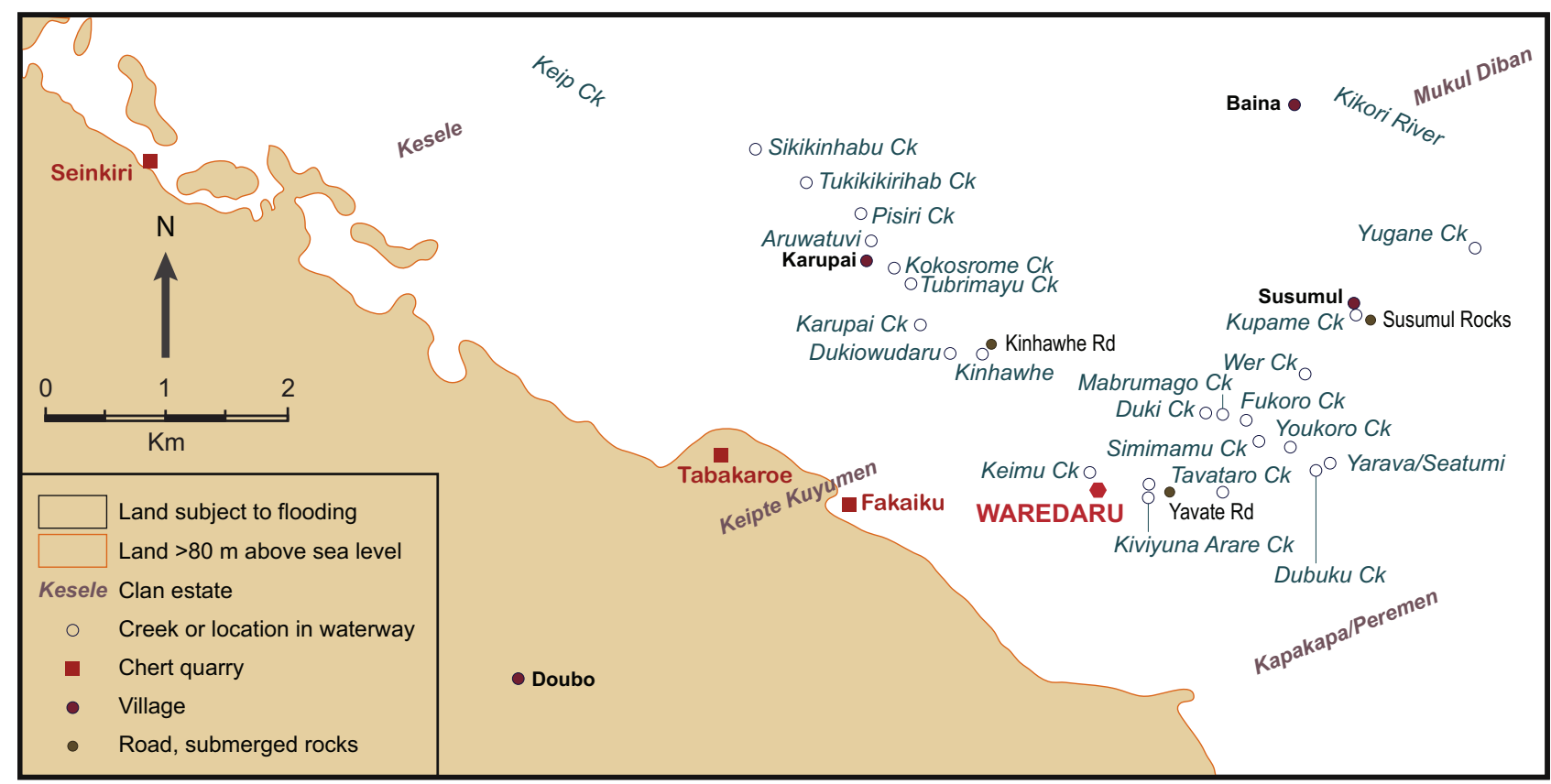

Figure 2 - Map of study area showing locations mentioned in text and visited named locations within or near the Keipte Kuyumen estate, as given by Wero Sisira during systematic field mapping in 2009. Clan estates are not included where clan estate boundaries were not visited.

Figure 2 - Contexte topographique de la zone d'étude ainsi que des lieux mentionnés dans le texte et lieux visités dans ou aux environs du territoire Keipte Kuyumen indiqués par Wero Sisira lors de la cartographie systématique du terrain en 2009 . Les frontières entre clans ne sont pas représentées.

pay for the land they planted sago and hunted in, thereby transferring ownership of the land to enable them to continue to hunt and plant sago. Various payments were then made during a major ceremony at the village of Waredaru that lay near the bank of Keip Creek and which already existed prior to these transactions. Waredaru and the nearby contemporaneous village of Amisago each had a longhouse, while Amisago's adjacent area Tago only had small houses. It was at Waredaru that the payments were made. Waredaru was the first village of the Keipte Kuyumen clan.

The 'big name' Kuyumen is the major clan name. Weiave's sago planting took place near the creek called Keip, and his general activities ranged from the junction of Keip Creek with the Kikori River. Kuyumen means 'we the people', Keip is the name of the creek, the suffix -te (from mute) means 'junction'; following the formal purchase of the land by Weiave's group, Weiave's people became formally known as Keipte Kuyumen (i.e. the Keipte sub-clan of the Kuyumen clan, now recognised as a clan in its own right). The name Keipte Kuyumen signals that their territory is adjacent to the junction of Keip Creek with the Kikori River."

In retelling the story of the purchase of Keipte Kuyumen clan lands at Waredaru, Wero Sisira pointed out that a very large agibo tree (fig. 3) today identifies the location of the past longhouse at Waredaru, but that this tree did not exist at the time of the village. The tree grew after the village and its longhouse had disappeared. The age of the village indicates the onset of formal recognition of Keipte Kuyumen lands and, with this, the foundation of the Keipte Kuyumen clan as a landed socio-political group distinct from the parent Kuyumen ancestral clan.

Wero Sisira emphasised that it was from the villages of Waredaru and Amisago that sago-pounders (called was in the local language; fig. 4, 5, 6) were manufactured in times past. He pointed out that some was were employed by Keipte Kuyumen women for the pounding of sago, while others were traded to residents of distant villages including Kantobo upstream of the Kikori River to the north and Kaiam, Kopi, Veiru and Ero downstream to the south (where stone for the manufacture of sagopounders does not occur).

This paper presents the results of archaeological work undertaken at Waredaru, a village site location only known from oral histories, the area today being entirely overgrown with rainforest. Villages abandoned in relatively recent times measured within the last century or so tend to have vegetational evidence of past village activity, such as the presence of bamboo stands, overgrown gardens or garden trees, but here no trace of such activity is evident today, indicating some considerable time since abandonment of the village. 


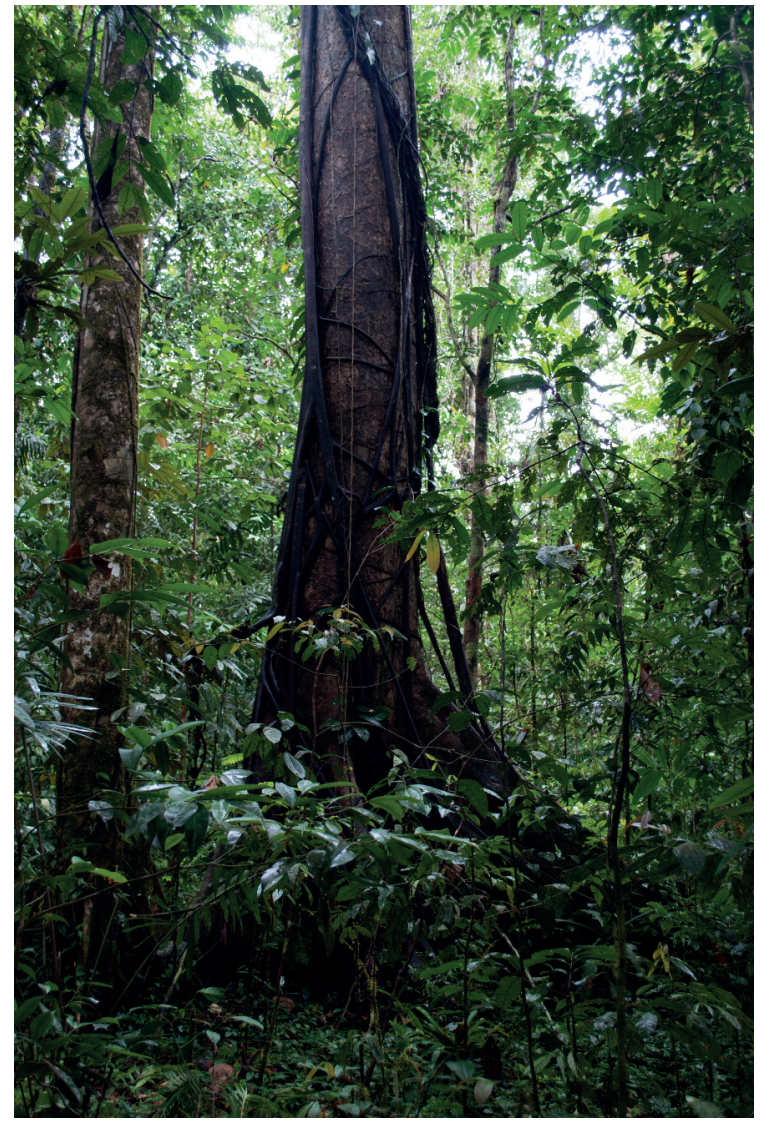

Figure 3 - Agibo tree at location of Waredaru village, 2009 (photograph: Bruno David).

Figure 3 - Arbre agibo situé au village de Waredaru, 2009 (photographie : Bruno David).

\section{Archaeological Investigations at Waredaru}

We were taken to the location of Waredaru in February 2009, where the agibo tree of the oral tradition was located. The village site is located $40 \mathrm{~m}$ southwest of Keip Creek, at Grid Reference UTM 54M 0794450 9234994 (AGD66). The archaeologists and Keipte Kuyumen clan representatives scanned the ground for a few hundred metres in all directions around the agibo tree of oral traditions for signs of an old village. Stone artefacts were found in the vicinity around an area of some $100 \mathrm{~m}$-diameter, in areas where erosion of the rainforest floor had exposed sub-surface levels; two small archaeological excavations were thereby undertaken in the thick rainforest-clad floodplain. Square A $(75 \mathrm{~cm} \times 75$ $\mathrm{cm}$ ) was positioned in a slightly elevated area devoid of erosion and without any surface evidence of cultural activity, in an area that Wero Sisira identified as the location of the village longhouse (fig. 7). Excavations were undertaken in mean $1.8 \pm 0.7 \mathrm{~cm}$ Excavation Units (XU) following the stratigraphy (tabl. 1). Excavated sediments were wet-sieved in $2 \mathrm{~mm}$ mesh sieves and all retained material bagged for sorting at the Monash University archaeology laboratories. The position within the square of stone artefacts $2 \mathrm{~cm}$ long was recorded in three-dimensions and the artefacts individually bagged. Bulk sediment samples for sediment analyses were taken of each XU. At the completion of the excavation, the walls of the square were photographed and sections drawn. The excavation went down 21 XUs to a maximum depth of $39 \mathrm{~cm}$ below ground to culturally sterile basal silty loam. The basal XU21 was sub-divided into three subXUs (a-c), with XU21b and XU21c consisting of localised patches of darker sediments from higher-level (SU1d) root disturbance.

Five Stratigraphic Units (SUs) were identified in Square A (tabl. 2 - fig. 8, 9):

SU1a: Very thin layer of loose surface leaf litter consisting of decomposing leaves and sticks in silty clay loam. Surface of underlying SU1b is fairly marked. Culturally sterile.

SU1b: Very humic (decomposed forest leaf litter soil), dark silty loam to silty clay loam, humid at time of excavation, rootlets abundant. Rootlets up to $1 \mathrm{~cm}-$ diameter present. Culturally sterile. Boundary with underlying SU1c not very distinct.

SU1c: Moderately consolidated and slightly compact silty loam to silty clay loam. Humid at time of excavation. This layer contains many large roots up to $6 \mathrm{~cm}$ in diameter along with numerous rootlets. Quantities of cultural materials increase rapidly at base of this SU down into SU1d. Interface with SU1d is gradual and marked by roots growing horizontally along the interface.

SU1d: Much like SU1c, consists of dark silty loam, here with noticeably fewer rootlets than SU1c, although rootlets are still abundant. This is the major cultural layer. Interface with SU2 is very gradual and mottled.

SU2: Thick, culturally sterile orange silty loam. Very consolidated and compact. Humid at time of excavation. Towards the centre of Square A, two localised patches of SU1d dark silty loam (XU21b and XU21c) penetrate deeper into SU2 than elsewhere in the square. Only the upper levels of SU2 incorporating minor amounts of down-worked SU1d interface sediments were excavated (as evidenced by gradating sediment texture and contents down the profile); the base of this SU was not reached.

Square B $(50 \mathrm{~cm} \times 50 \mathrm{~cm}$ ) was positioned approximately $25 \mathrm{~m}$ west of Square $A$ in an area with shallow surface erosion. It went down $18 \mathrm{XUs}$ to a maximum $37 \mathrm{~cm}$ depth to culturally sterile silty loam, in mean $2.1 \pm 0.4 \mathrm{~cm}$ XUs (tabl. 3 - fig. 10, 11). Excavation methods were the same as for Square A; the sequence of SUs was comparable, with the uppermost level consisting of a combined deflated SU1a and SU1b (tabl. 2). 
A

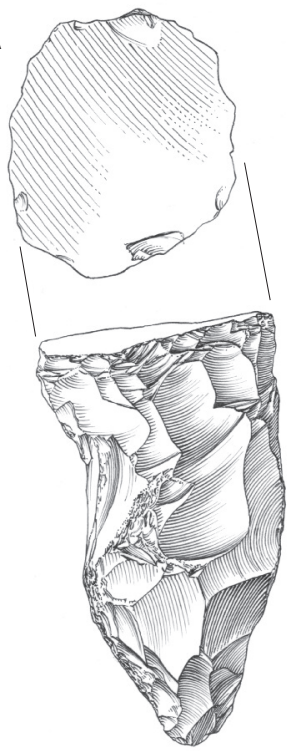

C

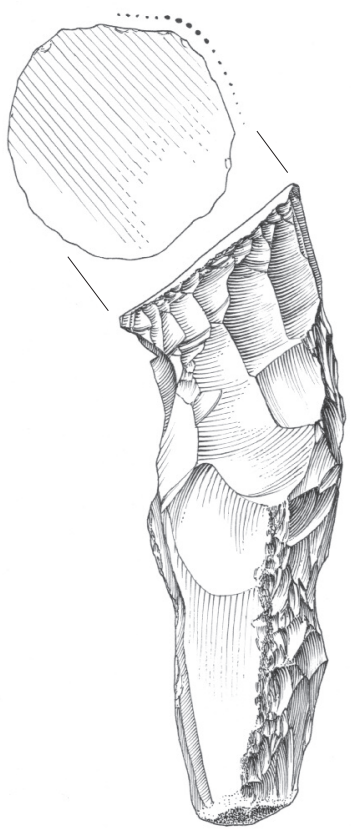

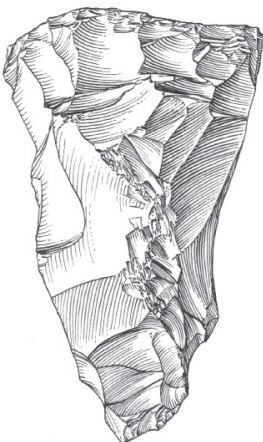

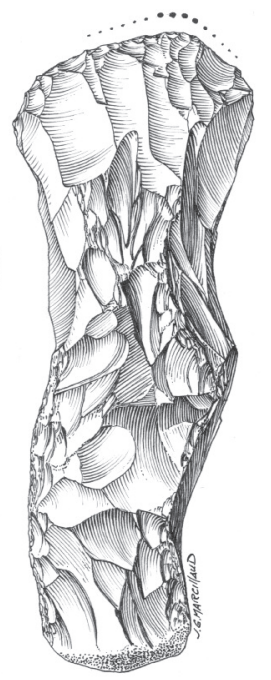

B

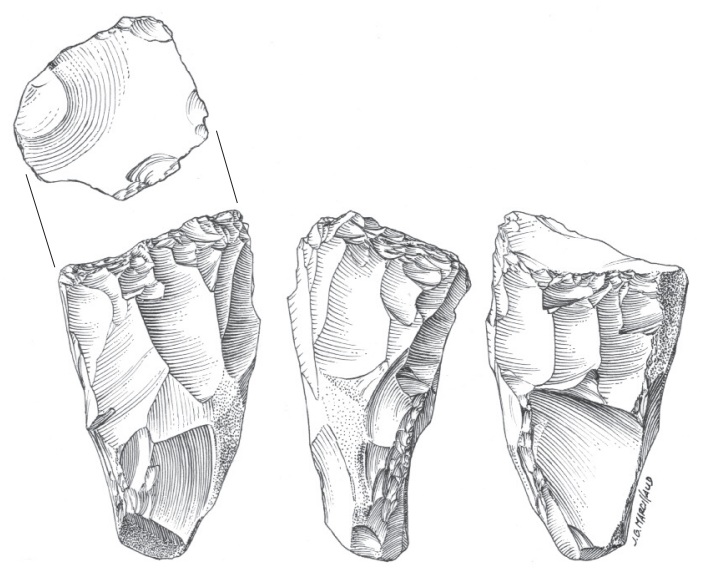

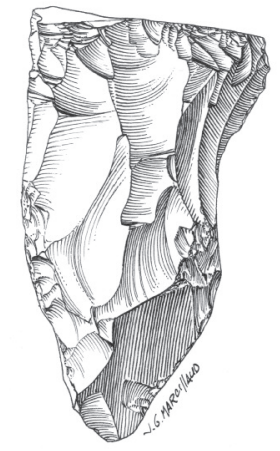

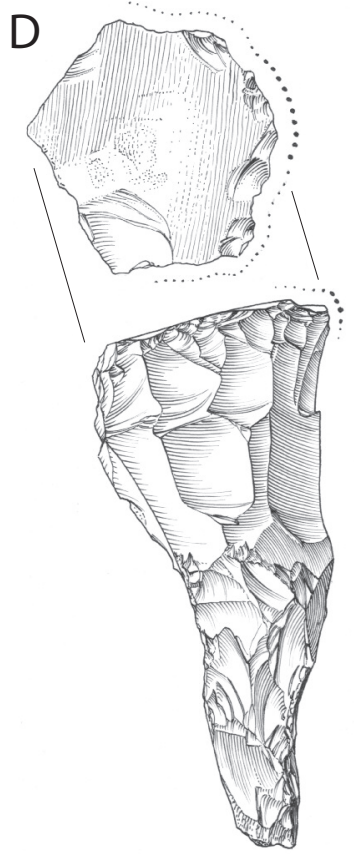

0

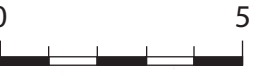

centimetres

Figure 4 - Stone sago-pounders from PNG National Museum \& Art Gallery Collection (drawing: Jean-Georges Marcillaud). A: From Fiwaga, Site LH5.5, dark gray chert, slightly grainy, heavily used and displaying a distinct polish around the planar active surface and along the arises. A brownish coating can be seen along the exposed active part. B: From Site LHS.4, fine-grained black chert with cortical remnants. Heavily used as indicated by a clear polish around the planar active surface and along the active part arises. The hafting area can be hardly distinguished but is made apparent by a zone of wear along the cortical area. C: From Gena'abo, Site LHU.1, matte black chert with limestone cortex. Slightly used. Two hafting areas are visible. Residue can be seen on the active part. D: From Site OJE, fine-grained black chert with cortical remnants. The sago pounder shows heavy use as evidenced by the extreme polish on the active planar surface (shiny mirror-like luster). The hafting area can be hardly distinguished. A brownish residue was observed in the recesses and along the hafted area.

Figure 4 - Herminettes à sago du Musée National de Papouasie Nouvelle Guinée et de galeries d'art (dessin : Jean-Georges Marcillaud). A: Provenant de Fiwaga, Site LH5.5, silex gris foncé légèrement grenu, très usé et poli très net sur tout le pourtour de la surface plane active et arêtes des bords actifs. La zone d'emmanchement est visible et un enduit brun peut être constaté sur zone exposée active. B: Provenant de LHS.4, silex noir à grain fin avec cortex résiduel, très usé, poli très net sur tout le pourtour de la surface plane active et arêtes des bords actifs. La zone d'emmanchement est difficile à distinguer mais perceptible par une usure de la zone de cortex à cet endroit. C: Provenant de Gena'abo, Site LHU.1, silex noir mat avec cortex crayeux blanc, peu usé. Deux zones d'emmanchement sont visibles. Dépôts sur la partie active. D: Provenant du site OJE, silex noir à grain fin avec zones corticales, très usé et poli extrême sur la face plane active (lustré brillant en miroir, comme vitrifié). La zone d'emmanchement est difficile à distinguer mais perceptible. Dépôt brun dans les creux et sur la zone emmanchée. 

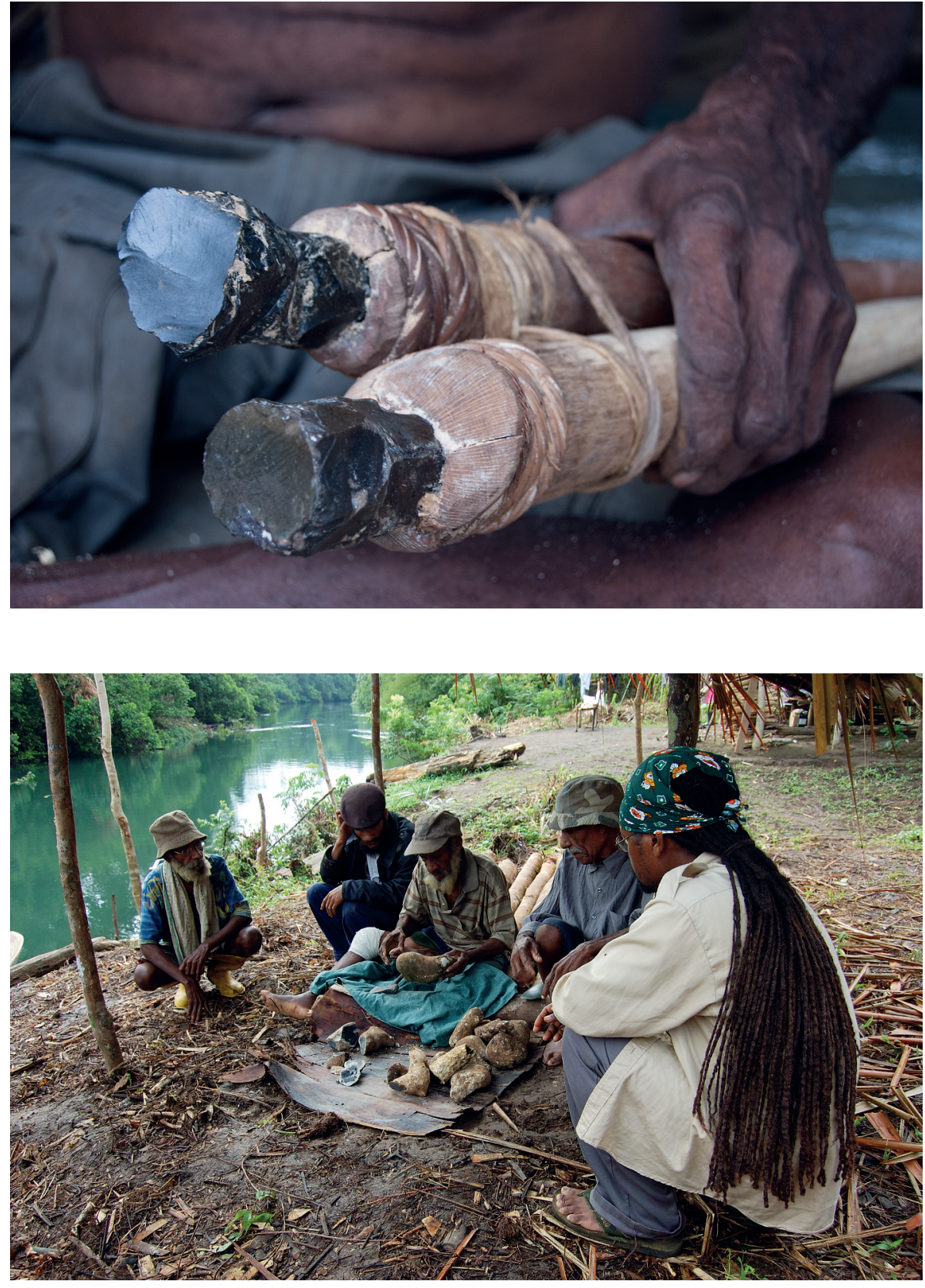

Figure 5 - Stone sago-pounders held in present-day Karupai houses, Keipte Kuyumen clan village, 2008 (photograph: Bruno David).

Figure 5 - Herminette à sago telle qu'elles se présentent aujourd'hui, Keipte Kuyumen village clanique (photographie : Bruno David).

Figure 6 - Wero Sisira flaking Tabakaroe chert nodules at Karupai village to make sago-pounders: initial checking of stone quality by removing cortex. On this occasion Wero could not personally travel to Tabakaroe due to an injury, thus testing the stone from the village base. From left to right: Kuto Sisira, Michael Wero, Wero Sisira, Mauke Omare, Nick Araho, 2008 (photograph: Bruno David).

Figure 6 - Wero Sisira taillant des nodules de silex Tabakaroe au village Karupai afin de fabriquer des têtes d'herminettes: le cortex est enlevé pour une inspection initiale de la qualité du silex. A cette occasion, Wero, blessé, ne pouvait pas se déplacer sur Tabakaroe pour tester lui même la qualité des rognons de silex. De gauche a droite : Kuto Sisira, Michael Wero, Wero Sisira, Mauke Omare, Nick Araho, 2008 (photographie : Bruno David).

\section{Trends in cultural materials}

Although no cultural materials were evident on the ground surface in the vicinity of Square A, excavation revealed culturally rich sub-surface deposits containing stone artefacts, animal bone, burnt clay and macroscopic charcoal peaking in XU3 to XU15 $(2 \mathrm{~cm}$ to $27 \mathrm{~cm}$ below ground) (tabl. 4 - fig. 12). This dense cultural horizon is consistent with the presence of a village, in agreement with the oral traditions.

Nine AMS radiocarbon determinations were obtained on charcoal from Square $A$ and a single charcoal sample from Square B (tabl. 5). To better define the duration of site use covered by the seven dates of the upper cultural horizon, we have used OxCal v4.2 (Bronk-Ramsey 2013) to determine the age of onset, end and duration of the various midden deposits at Waredaru. Using a phase command (i.e. assuming that the seven youngest dates from layer SU1 (XU21b and above) are not from an instantaneous event but a random scatter of events in no particular order) with a uniform boundary (Bronk-Ramsey 2009), we get a modelled age for the top of Square A of $149-284$ cal BP at $68.2 \%$ probability (about eight to 14 generations ago based on a 25-year generation spacing) (tabl. 6). These younger deposits were in use for between seven and 38 years. The village of Waredaru is located in thick rainforest and the incorporation of old 


\begin{tabular}{|c|c|c|c|c|c|c|c|c|c|}
\hline$X U$ & su & $\begin{array}{l}\text { Mean } \\
\text { Depth } \\
\text { at Top } \\
(\mathrm{cm}) \\
\end{array}$ & $\begin{array}{c}\text { Mean } \\
\text { Depth at } \\
\text { Centre } \\
\text { (cm) }\end{array}$ & $\begin{array}{l}\text { Mean } \\
\text { Depth at } \\
\text { Base } \\
(\mathrm{cm})\end{array}$ & $\begin{array}{l}\text { Mean } \\
\text { Thickness } \\
\text { (cm) }\end{array}$ & $\begin{array}{l}\text { Area } \\
\left(\mathrm{m}^{2}\right)\end{array}$ & $\begin{array}{l}\text { Weight } \\
\text { (kg) }\end{array}$ & $\begin{array}{c}\text { Volume } \\
\text { (litres) }\end{array}$ & pH \\
\hline 1 & $1 \mathrm{a}$ & 0.0 & 0.3 & 0.6 & 0.6 & 0.56 & 3.2 & 7.0 & 4.24 \\
\hline 2 & $1 b+1 c$ & 0.6 & 1.5 & 2.4 & 1.8 & 0.56 & 8.7 & 14.5 & 4.24 \\
\hline 3 & $1 \mathrm{c}$ & 2.4 & 4.2 & 5.9 & 3.5 & 0.56 & 13.1 & 25.5 & 4.26 \\
\hline 4 & $1 c+1 d$ & 5.9 & 7.4 & 8.9 & 3.0 & 0.56 & 16.4 & 22.0 & 4.28 \\
\hline 5 & $1 c+1 d$ & 8.9 & 9.1 & 9.3 & 0.4 & 0.56 & 4.4 & 6.0 & 4.35 \\
\hline 6 & $1 d$ & 9.3 & 10.5 & 11.6 & 2.3 & 0.56 & 13.9 & 18.0 & 4.43 \\
\hline 7 & $1 \mathrm{~d}$ & 11.6 & 12.4 & 13.2 & 1.6 & 0.56 & 14.9 & 19.0 & 4.43 \\
\hline 8 & $1 d$ & 13.2 & 14.1 & 14.9 & 1.7 & 0.56 & 12.6 & 15.0 & 4.48 \\
\hline 9 & $1 d$ & 14.9 & 15.8 & 16.6 & 1.7 & 0.56 & 11.9 & 14.0 & 4.54 \\
\hline 10 & $1 d+2$ & 16.6 & 17.2 & 17.8 & 1.2 & 0.56 & 10.3 & 8.5 & 4.70 \\
\hline 11 & $1 d+2$ & 17.8 & 18.6 & 19.4 & 1.6 & 0.56 & 15.0 & 18.0 & 4.18 \\
\hline 12 & $1 d+2$ & 19.4 & 20.3 & 21.2 & 1.8 & 0.56 & 16.0 & 18.5 & \\
\hline 13 & $1 d+2$ & 21.2 & 21.9 & 22.5 & 1.3 & 0.56 & 12.7 & 16.0 & 4.50 \\
\hline 14 & $1 d+2$ & 22.5 & 23.5 & 24.4 & 1.9 & 0.56 & 16.4 & 20.0 & 4.50 \\
\hline 15 & $1 d+2$ & 24.4 & 25.6 & 26.8 & 2.4 & 0.56 & 20.0 & 25.0 & 4.28 \\
\hline 16 & $1 d+2$ & 26.8 & 27.6 & 28.3 & 1.5 & 0.56 & 14.4 & 17.0 & 4.44 \\
\hline 17 & $1 d+2$ & 28.3 & 29.5 & 30.6 & 2.3 & 0.56 & 19.4 & 22.0 & 4.46 \\
\hline 18 & $1 d+2$ & 30.6 & 31.4 & 32.1 & 1.5 & 0.56 & 14.8 & 18.0 & 4.52 \\
\hline 19 & $1 d+2$ & 32.1 & 33.4 & 34.7 & 2.6 & 0.56 & 20.3 & 24.5 & 4.54 \\
\hline 20 & $1 d+2$ & 34.7 & 35.4 & 36.1 & 1.4 & 0.56 & 11.2 & 13.0 & 4.53 \\
\hline $21 a$ & $1 \mathrm{~d}+2$ & 36.1 & 37.4 & 38.6 & 2.5 & 0.52 & 25.2 & 31.0 & 4.63 \\
\hline $21 b$ & $1 d+2$ & 36.1 & 37.4 & 38.6 & 2.5 & 0.04 & 1.1 & 1.0 & \\
\hline $21 \mathrm{c}$ & $1 d+2$ & 36.1 & 37.4 & 38.6 & 2.5 & 0.01 & 0.2 & $<0.5$ & \\
\hline Total & & & & & $1.8 \pm 0.7$ & & 295.1 & 374.0 & \\
\hline
\end{tabular}

Table 1 - Details of XUs, Waredaru Square $A$.

Tableau 1 - Détails des unités stratigraphiques, Waredaru Carré A.

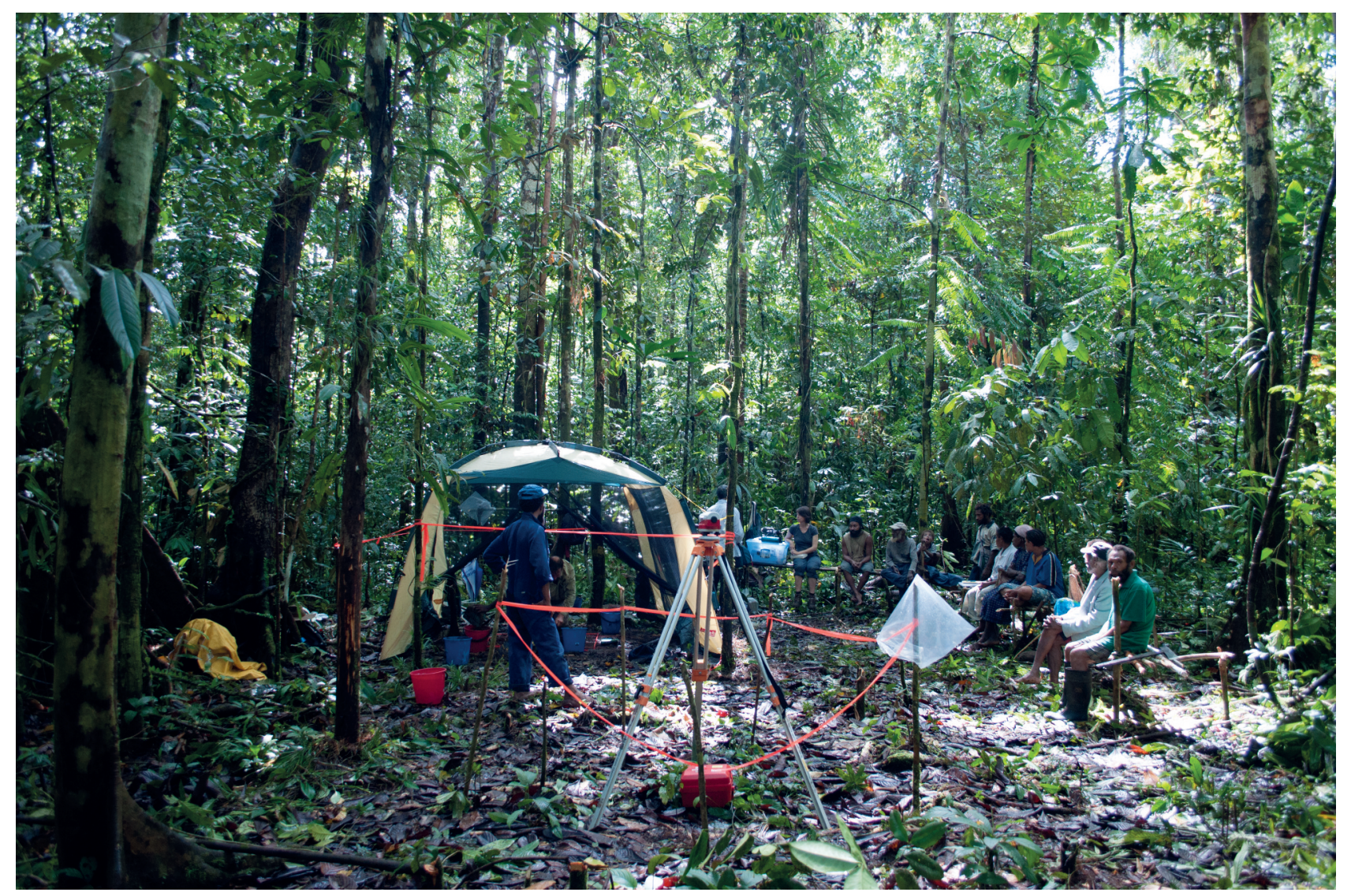

Figure 7 - Waredaru Square A, archaeological excavations in progress, 2009 (photograph: Bruno David).

Figure 7 - Waredaru Carré A lors des fouille archéologiques de 2009 (photographie : Bruno David). 


\begin{tabular}{|c|c|c|c|c|c|c|c|c|}
\hline \multirow[b]{2}{*}{ XU } & \multirow[b]{2}{*}{$\begin{array}{c}\text { Organic } \\
\text { matter } \\
(\%)\end{array}$} & \multirow[b]{2}{*}{$\begin{array}{c}\text { Particles } \\
>1000 \mu \mathrm{m} \\
\text { (\% weight) }\end{array}$} & \multicolumn{6}{|c|}{ Particle size distribution of particles $\leq 1000 \mu \mathrm{m}$ (\% volume) } \\
\hline & & & $\begin{array}{l}\text { sand } \\
(1000-63 \\
\mu \mathrm{m})\end{array}$ & $\begin{array}{c}\text { coarse } \\
\text { sand } \\
(1000- \\
600 \mu \mathrm{m})\end{array}$ & $\begin{array}{c}\text { medium } \\
\text { sand }(600 \\
-212 \mu \mathrm{m})\end{array}$ & $\begin{array}{c}\text { fine sand } \\
(212-63 \\
\mu \mathrm{m})\end{array}$ & $\begin{array}{c}\text { silt }(63-2 \\
\mu \mathrm{m})\end{array}$ & $\begin{array}{c}\text { clay }(<2 \\
\mu \mathrm{m})\end{array}$ \\
\hline \multicolumn{9}{|c|}{ Square $\mathrm{A}$} \\
\hline 1 & 51.7 & 0.2 & 0.3 & 0.0 & 0.0 & 0.3 & 72.8 & 26.9 \\
\hline 2 & 33.1 & 1.0 & 1.9 & 0.0 & 0.0 & 1.9 & 72.1 & 26.0 \\
\hline 3 & 28.5 & 0.4 & 3.4 & 0.0 & 0.0 & 3.4 & 71.0 & 25.6 \\
\hline 4 & 21.0 & 0.1 & 5.5 & 0.0 & 0.0 & 5.5 & 75.0 & 19.5 \\
\hline 5 & 17.9 & 0.3 & 0.1 & 0.0 & 0.0 & 0.1 & 79.2 & 20.7 \\
\hline 6 & 16.0 & 0.2 & 0.0 & 0.0 & 0.0 & 0.0 & 80.1 & 19.9 \\
\hline 7 & 15.2 & 0.5 & 0.0 & 0.0 & 0.0 & 0.0 & 78.3 & 21.7 \\
\hline 8 & 14.0 & 0.7 & 3.5 & 0.0 & 0.0 & 3.5 & 76.9 & 19.6 \\
\hline 9 & 13.7 & 0.6 & 6.8 & 0.0 & 0.0 & 6.8 & 75.9 & 17.3 \\
\hline 10 & 15.3 & 0.1 & 5.7 & 0.0 & 0.0 & 5.7 & 77.3 & 17.0 \\
\hline 11 & 13.3 & 0.5 & 15.9 & 0.0 & 0.0 & 15.9 & 68.0 & 16.1 \\
\hline 13 & 12.4 & 0.4 & 23.6 & 0.0 & 0.1 & 23.5 & 62.7 & 13.7 \\
\hline 14 & 11.8 & 0.3 & 25.8 & 0.0 & 0.0 & 25.8 & 60.9 & 13.3 \\
\hline 15 & 11.3 & 0.2 & 29.8 & 0.0 & 0.0 & 29.8 & 57.4 & 12.8 \\
\hline 16 & 11.2 & 0.1 & 32.2 & 0.0 & 0.0 & 32.2 & 55.5 & 12.3 \\
\hline 17 & 10.5 & 0.2 & 22.4 & 0.0 & 0.0 & 22.4 & 63.0 & 14.6 \\
\hline 18 & 10.4 & 0.1 & 36.1 & 0.0 & 0.1 & 36.0 & 51.7 & 12.2 \\
\hline 19 & 10.1 & 0.2 & 37.1 & 0.0 & 0.1 & 37.0 & 50.9 & 12.0 \\
\hline 20 & 10.4 & 0.2 & 32.8 & 0.0 & 0.0 & 32.8 & 54.9 & 12.3 \\
\hline $21 a$ & 9.7 & 0.1 & 30.9 & 0.0 & 0.2 & 30.7 & 56.1 & 13.0 \\
\hline \multicolumn{9}{|c|}{ Square B } \\
\hline 1 & 24.2 & 0.20 & 20.6 & 0.3 & 4.8 & 15.5 & 61.6 & 17.8 \\
\hline 2 & 17.6 & 3.60 & 8.0 & 0.0 & 0.1 & 7.9 & 73.0 & 19.0 \\
\hline 3 & 14.9 & 0.19 & 9.2 & 0.0 & 0.2 & 9.0 & 78.1 & 12.7 \\
\hline 4 & 12.6 & 0.42 & 33.0 & 0.0 & 0.1 & 32.9 & 57.5 & 9.5 \\
\hline 5 & 11.9 & 0.20 & 38.5 & 0.0 & 0.0 & 38.5 & 53.2 & 8.3 \\
\hline 6 & 11.4 & 0.14 & 42.4 & 0.0 & 0.1 & 42.3 & 49.6 & 8.0 \\
\hline 7 & 10.6 & 0.15 & 35.8 & 0.0 & 0.0 & 35.8 & 55.6 & 8.6 \\
\hline 8 & 10.0 & 0.08 & 46.1 & 0.0 & 0.1 & 46.0 & 46.3 & 7.6 \\
\hline 9 & 9.7 & 0.30 & 48.6 & 0.0 & 0.1 & 48.5 & 44.2 & 7.2 \\
\hline 10 & 9.3 & 0.23 & 29.3 & 0.0 & 0.0 & 29.3 & 59.3 & 11.4 \\
\hline 11 & 9.0 & 0.11 & 34.4 & 0.0 & 0.0 & 34.4 & 54.7 & 10.9 \\
\hline 12 & 9.2 & 0.58 & 37.1 & 0.0 & 0.0 & 37.1 & 53.3 & 9.6 \\
\hline 13 & 8.5 & 0.04 & 45.7 & 0.0 & 0.2 & 45.5 & 45.5 & \begin{tabular}{|l|l|}
8.8 \\
\end{tabular} \\
\hline 14 & 9.0 & 0.00 & 39.8 & 0.0 & 0.0 & 39.8 & 49.9 & 10.3 \\
\hline 15 & 8.9 & 0.04 & 48.6 & 0.0 & 0.2 & 48.4 & 43.4 & 8.0 \\
\hline 16 & 8.5 & 0.04 & 45.5 & 0.0 & 0.2 & 45.3 & 45.4 & 9.1 \\
\hline 17 & 7.8 & 0.09 & 50.5 & 0.0 & 4.5 & 46.0 & 39.3 & 10.2 \\
\hline 18 & 8.2 & 0.02 & 50.4 & 0.0 & 4.8 & 45.6 & 39.1 & 10.5 \\
\hline
\end{tabular}

Table 2 - Details of excavated sediments by XU, Waredaru Squares $A$ and $B$.

Tableau 2 - Détails des sédiments par XU, Waredaru Carré $A$ et Carré $B$.

wood could be a problem with this interpretation of site age, although as ethnographically smaller (and younger) trees and branches rather than the centre of the trunk of large (and older) trees are usually used for firewood in this region, these ages are likely to be accurate approximations. Because we are limited in this example to samples of wood charcoal, we have not explored this further.

Two charcoal samples from XU15 and XU18 beneath these levels indicate an earlier phase of cultural activity starting around 1931-1276 cal BP, but this earlier phase is not associated with distinguishable peaks in cultural materials other than a minor peak in charcoal. It was not possible to estimate the span of the older deposit because of the small number of dates obtained. As natural bushfires are entirely unknown in this wet rainforest setting (e.g. Hopkins et al. 1993 - p. 368; Paijmans and Rollet 1977 - p. 126-127), the charcoal from both cultural phases is arguably anthropogenic.

Table 4 shows the quantity of cultural remains recovered from each $X U$ in Square $A$, while graphs presented in Figure 12 show the changing densities of burnt clay and charcoal through the deposit. The charcoal, burnt clay and animal bones (all of which are calcined) most likely represent a unified assemblage derived from the regular cleaning out of fire-pits from the longhouse or nearby houses of Wero Sisira's local oral traditions, as recounted above. Directly comparable assemblages can be 


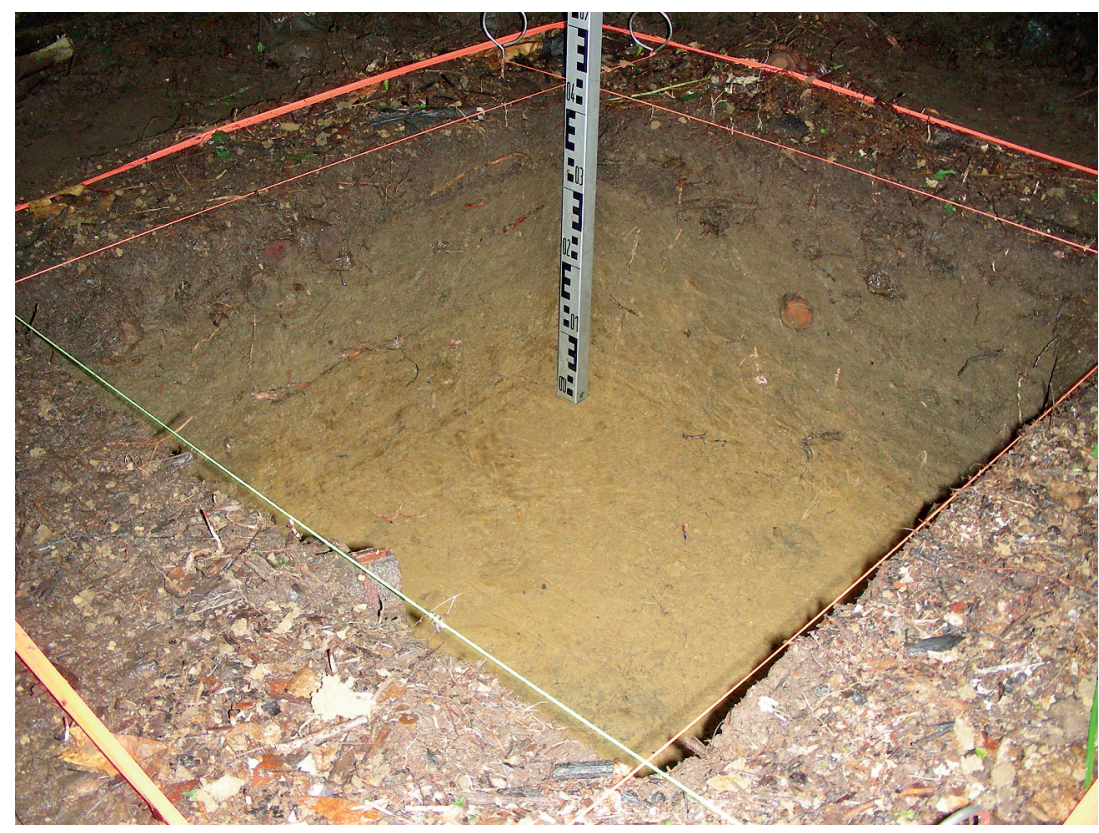

Figure 8 - Waredaru Square A after completion of archaeological excavations: west and north walls, 2009 (photograph: Bruno David).

Figure 8 - Waredaru Carré A parois ouest et nord en fin de fouille, 2009 (photographie : Bruno David).

WEST

NORTH
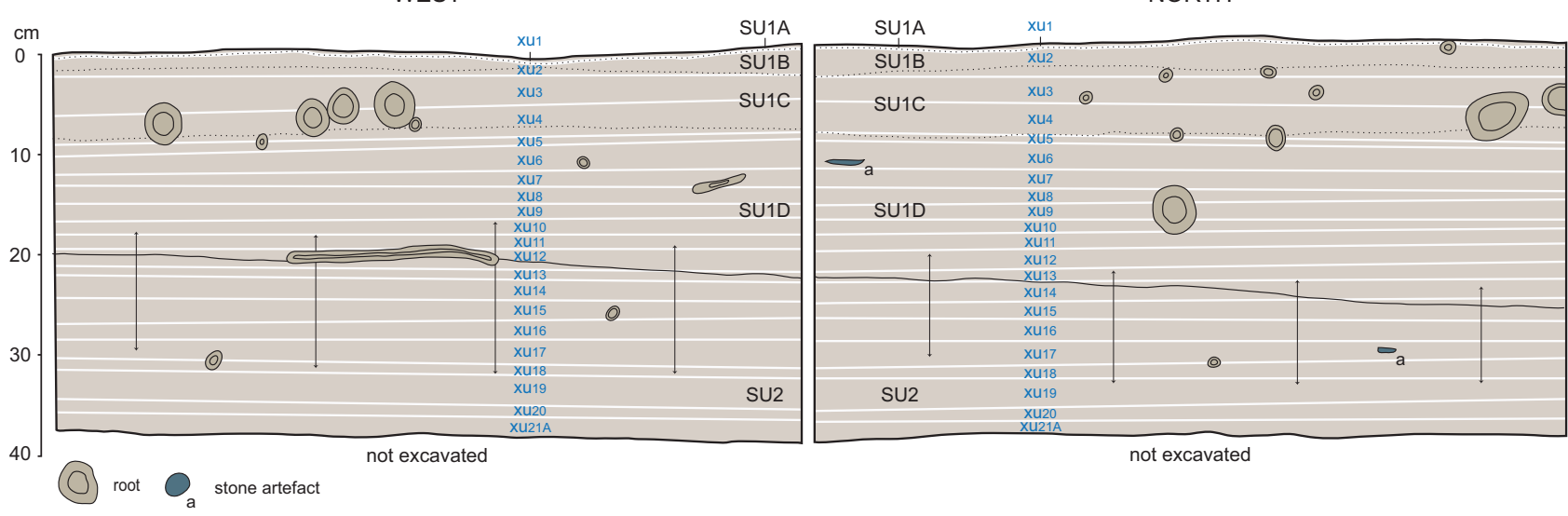

Figure 9 - West and north sections, with XUs back-plotted, Waredaru Square A. Vertical arrows represent stratigraphic interface as indicated by zone of gradual sediment colour and texture change.

Figure 9 - Coupe stratigraphique des parois ouest et nord de Waredaru, Carré A incluant les unités de stratigraphie. Les flèches verticales représentent la zone d'interface entre deux couches lorsque la couleur et la texture des sédiments changent graduellement.

observed today in the vicinity of village or garden houses across the Highlands foothills, wherever people maintain regular fireplaces over extended periods of time (fig. 13).

In Square B cultural deposits were largely restricted to stone artefacts, with minor amounts of burnt earth in some XUs and a single small piece of charcoal from XU3 (tabl. 6); no animal bone was recovered. Here stone artefacts overwhelmingly come from the near-surface XU2-XU8 and show decreasing numbers with depth (fig. 14). A single radiocarbon date of ca. 3000 cal BP from XU3 (tabl. 5) indicates the presence of people earlier than evident in Square A, although the bulk, and possibly all of the stone artefacts appear on and immediately below the deflated surface of the square within SU1 (and especially within SU1d, as is the case also in Square A) and therefore date to the same main occupation period around $200 \mathrm{cal} \mathrm{BP}$ as the upper phase of Square A. The Square $B$ radiocarbon date comes from a stratigraphic level with large roots and thus probably indicates the post-depositional intrusion of a tiny piece of charcoal (weighing $0.02 \mathrm{~g}$ ) from deeper stratigraphic levels (SU2) through root action. 


\begin{tabular}{|c|c|c|c|c|c|c|c|c|c|}
\hline XU & SU & $\begin{array}{l}\text { Mean } \\
\text { Depth } \\
\text { at Top } \\
\text { (cm) }\end{array}$ & $\begin{array}{l}\text { Mean } \\
\text { Depth at } \\
\text { Centre } \\
\text { (cm) }\end{array}$ & $\begin{array}{l}\text { Mean } \\
\text { Depth } \\
\text { at Base } \\
(\mathrm{cm})\end{array}$ & $\begin{array}{c}\text { Mean } \\
\text { Thickness } \\
(\mathbf{c m})\end{array}$ & $\begin{array}{c}\text { Area } \\
\left(m^{2}\right)\end{array}$ & $\begin{array}{c}\text { Weight } \\
\text { (kg) }\end{array}$ & $\begin{array}{l}\text { Volume } \\
\text { (litres) }\end{array}$ & $\mathrm{pH}$ \\
\hline 1 & $1 a+1 b+1 c$ & 0.0 & 0.9 & 1.8 & 1.8 & 0.25 & 4.8 & 8.0 & 4.49 \\
\hline 2 & $1 \mathrm{c}+1 \mathrm{~d}$ & 1.8 & 3.1 & 4.4 & 2.6 & 0.25 & 6.3 & 8.0 & 4.50 \\
\hline 3 & $1 d$ & 4.4 & 5.5 & 6.6 & 2.2 & 0.25 & 7.7 & 11.0 & 4.58 \\
\hline 4 & $1 d$ & 6.6 & 7.7 & 8.8 & 2.2 & 0.25 & 8.5 & 10.0 & 4.65 \\
\hline 5 & $1 d+2$ & 8.8 & 10.3 & 11.8 & 3.0 & 0.25 & 9.1 & 12.0 & 4.61 \\
\hline 6 & $1 d+2$ & 11.8 & 12.7 & 13.6 & 1.8 & 0.25 & 7.1 & 9.0 & 4.57 \\
\hline 7 & $1 d+2$ & 13.6 & 14.8 & 15.9 & 2.3 & 0.25 & 8.2 & 11.0 & 4.57 \\
\hline 8 & $1 d+2$ & 15.9 & 16.9 & 17.8 & 1.9 & 0.25 & 7.4 & 10.0 & 4.62 \\
\hline 9 & $1 d+2$ & 17.8 & 18.9 & 19.9 & 2.1 & 0.25 & 7.1 & 10.0 & 4.68 \\
\hline 10 & $1 d+2$ & 19.9 & 20.8 & 21.7 & 1.8 & 0.25 & 6.8 & 9.0 & 4.52 \\
\hline 11 & $1 d+2$ & 21.7 & 22.8 & 23.8 & 2.1 & 0.25 & 8.2 & 10.0 & 3.69 \\
\hline 12 & $1 d+2$ & 23.8 & 24.6 & 25.3 & 1.5 & 0.25 & 6.1 & 7.5 & 3.71 \\
\hline 13 & $1 d+2$ & 25.3 & 26.1 & 26.9 & 1.6 & 0.25 & 6.4 & 8.0 & 3.89 \\
\hline 14 & 2 & 26.9 & 27.8 & 28.6 & 1.7 & 0.25 & 7.5 & 10.5 & 3.77 \\
\hline 15 & 2 & 28.6 & 29.6 & 30.5 & 1.9 & 0.25 & 8.7 & 10.0 & 3.77 \\
\hline 16 & 2 & 30.5 & 31.7 & 32.8 & 2.3 & 0.25 & 8.8 & 11.0 & 3.78 \\
\hline 17 & 2 & 32.8 & 33.6 & 34.4 & 1.6 & 0.25 & 7.4 & 9.0 & 3.86 \\
\hline 18 & 2 & 34.4 & 35.7 & 36.9 & 2.5 & 0.25 & 11.0 & 15.0 & 3.92 \\
\hline Total & & & & & $2.1 \pm 0.4$ & & 137.1 & 179.0 & \\
\hline
\end{tabular}

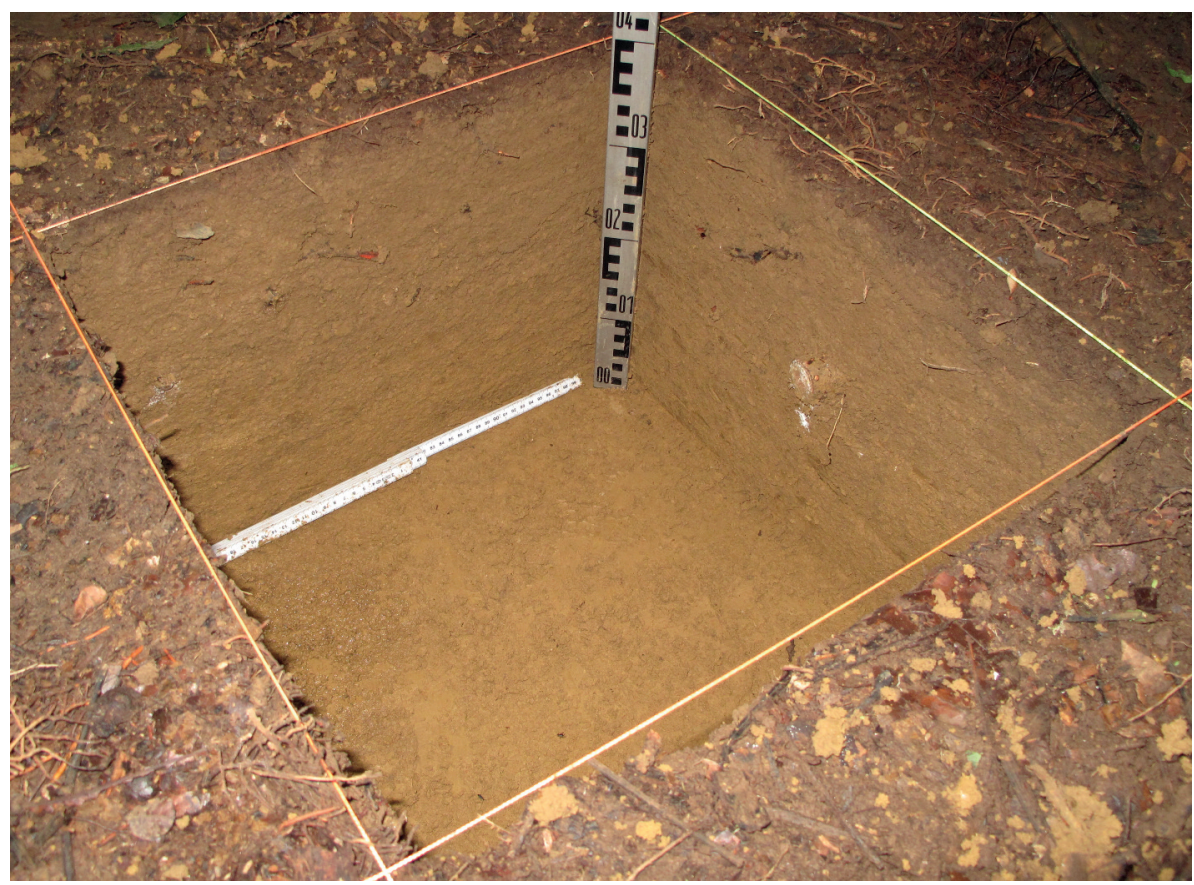

Table 3 - Details of XUs, Waredaru Square $B$.

Tableau 3 - Détails des unités stratigraphiques, Waredaru Carré $B$.
Figure 10 - Waredaru Square B after completion of archaeological excavations: south and east walls (photograph: Robert Skelly).

Figure 10 - Waredaru Carré B parois sud et est en fin de fouille, 2009 (photographie : Robert Skelly).

\section{The animal bone}

Very small amounts of animal bone were recovered from XU4 to XU15 in Square A. All recovered bone is thoroughly calcined and most fragments measure no more than $5 \mathrm{~mm}$ in maximum length. Based on a combination of morphological and surface textural features of the bone, it was possible to recognise fragments derived from three groups of vertebrates: fish, mammals and snakes (tabl. 7). Very small or nondescript fragments remain 'unidentified'.
None of the fish or mammal bone is diagnostic at lower taxonomic levels. However, from the size of the fish and mammal bone fragments, we can infer that the fish were in the weight range $500 \pm 250 \mathrm{~g}$ and that the mammals included cuscus- to wallaby-sized species. The snake remains consist of two fragments of python dentary (Family Boidae), from an individual in the size range 1-2 $m$ body length.

Some fragments from the lower levels of the deposit show rounding of fracture edges consistent with solutional degradation. However, fracture edges on most 


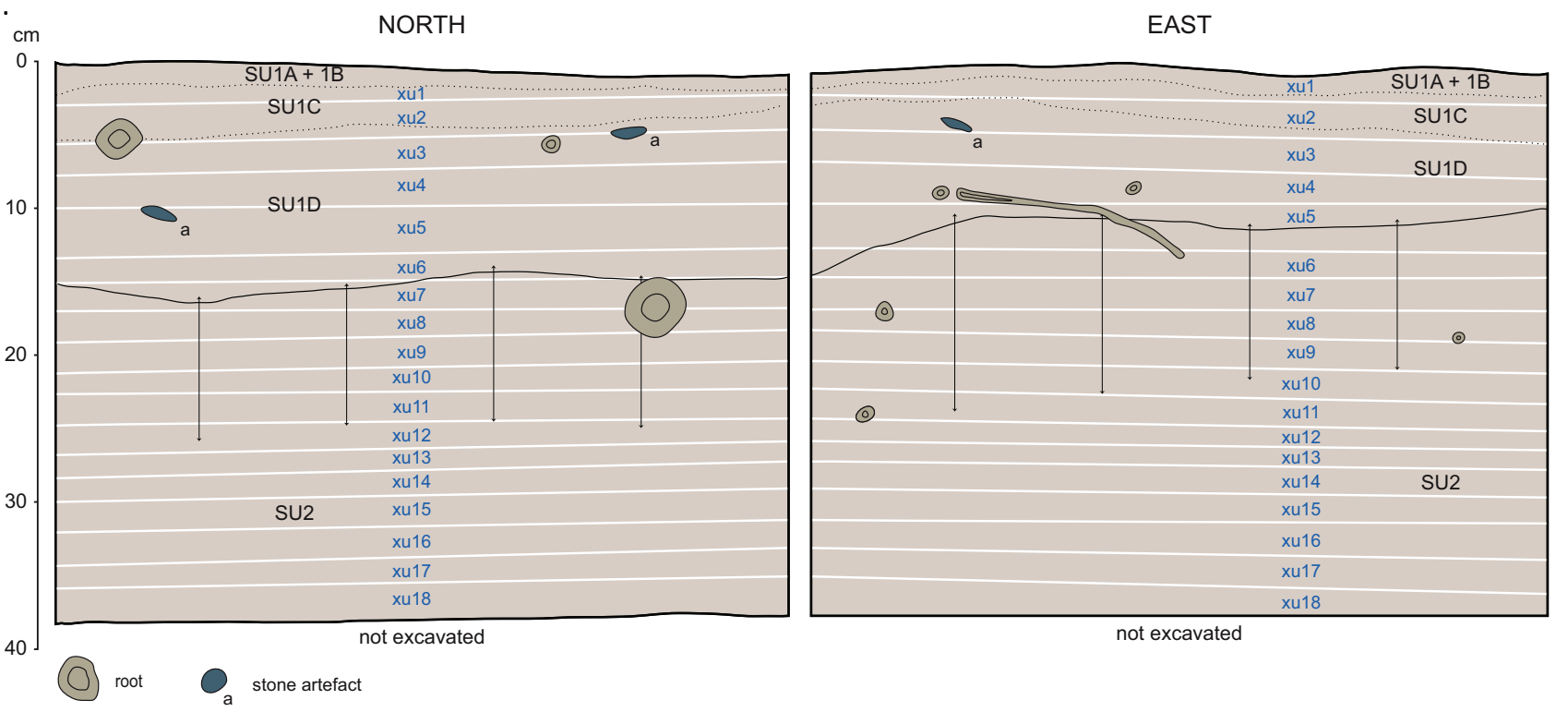

Figure 11 - North and east sections, with XUs back-plotted, Waredaru Square B. Vertical arrows represent stratigraphic interface as indicated by zone of gradual sediment colour and texture change.

Figure 11 - Coupe stratigraphique des parois nord et est de Waredaru, Carré B incluant les unités de stratigraphie. Les flèches verticales représentent la zone d'interface entre deux couches lorsque la couleur et la texture des sédiments changent graduellement.

\begin{tabular}{|c|c|c|c|c|c|c|}
\hline \multirow{2}{*}{$\mathbf{X U}$} & \multirow{2}{*}{ su } & Animal Bone & Charcoal & Burnt Earth & Stone Artefacts & Stone Artefacts \\
\hline & & (g) & (g) & (g) & $(\#)$ & (g) \\
\hline 1 & $1 a$ & & & & & \\
\hline 2 & $1 b+1 c$ & & & 11.3 & 2 & 0.1 \\
\hline 3 & $1 c$ & 0.29 & 0.66 & 95.7 & 45 & 1.5 \\
\hline 4 & $1 c+1 d$ & 1.23 & & 280.5 & 87 & 12.2 \\
\hline 5 & $1 c+1 d$ & & 0.67 & 147.8 & 21 & 76.5 \\
\hline 6 & $1 d$ & 0.72 & 1.69 & 770.1 & 97 & 141.2 \\
\hline 7 & $1 d$ & 0.45 & 1.08 & 1229.0 & 94 & 57.4 \\
\hline 8 & $1 d$ & 0.46 & 0.19 & 119.4 & 59 & 34.3 \\
\hline 9 & $1 d$ & 0.27 & 0.15 & 64.4 & 46 & 24.9 \\
\hline 10 & $1 d+2$ & & 0.01 & 25.4 & 20 & 4.0 \\
\hline 11 & $1 d+2$ & 0.03 & 0.49 & 31.1 & 39 & 15.7 \\
\hline 12 & $1 d+2$ & 0.02 & 0.03 & 210.1 & 27 & 5.9 \\
\hline 13 & $1 d+2$ & & 0.25 & 18.5 & 12 & 1.8 \\
\hline 14 & $1 d+2$ & & 0.23 & 11.8 & 17 & 79.2 \\
\hline 15 & $1 d+2$ & 0.02 & 0.29 & 7.2 & 16 & 0.9 \\
\hline 16 & $1 d+2$ & & 0.01 & 3.6 & 3 & 0.0 \\
\hline 17 & $1 d+2$ & & 0.01 & 1.2 & 5 & 0.2 \\
\hline 18 & $1 d+2$ & & 0.20 & 1.8 & 3 & 0.1 \\
\hline 19 & $1 d+2$ & & 0.02 & 1.1 & 3 & 29.9 \\
\hline 20 & $1 d+2$ & & 0.00 & 0.7 & 1 & 0.2 \\
\hline $21 a$ & $1 d+2$ & & 0.00 & 0.1 & 3 & 3.9 \\
\hline $21 b$ & $1 d+2$ & & 0.03 & 0.0 & & \\
\hline $21 c$ & $1 d+2$ & & 0.00 & 0.0 & & \\
\hline Total & & 3.49 & 6.01 & 3030.8 & 600 & 490.0 \\
\hline
\end{tabular}

Table 4 - Cultural contents, Waredaru Square $A$.

Tableau 4 - Contenu culturel, Waredaru Carré $A$. fragments from the upper XUs are relatively sharp, hence it is worth considering whether the small quantity of bone in these XUs is an original feature of the assemblage or a product of post-depositional loss.

Given the exposed nature of the deposit and the lack of any unburnt or even lightly burnt bone among the surviving remains, it seems likely that the great bulk of any original assemblage has been destroyed. Much of this may have occurred prior to burial of the remains through scavenging by dogs and pigs, both of which will consume fresh bone that retains organic food value. In addition, bone that is either unburnt or only lightly burnt (i.e., still retains some organic matter) is particularly 


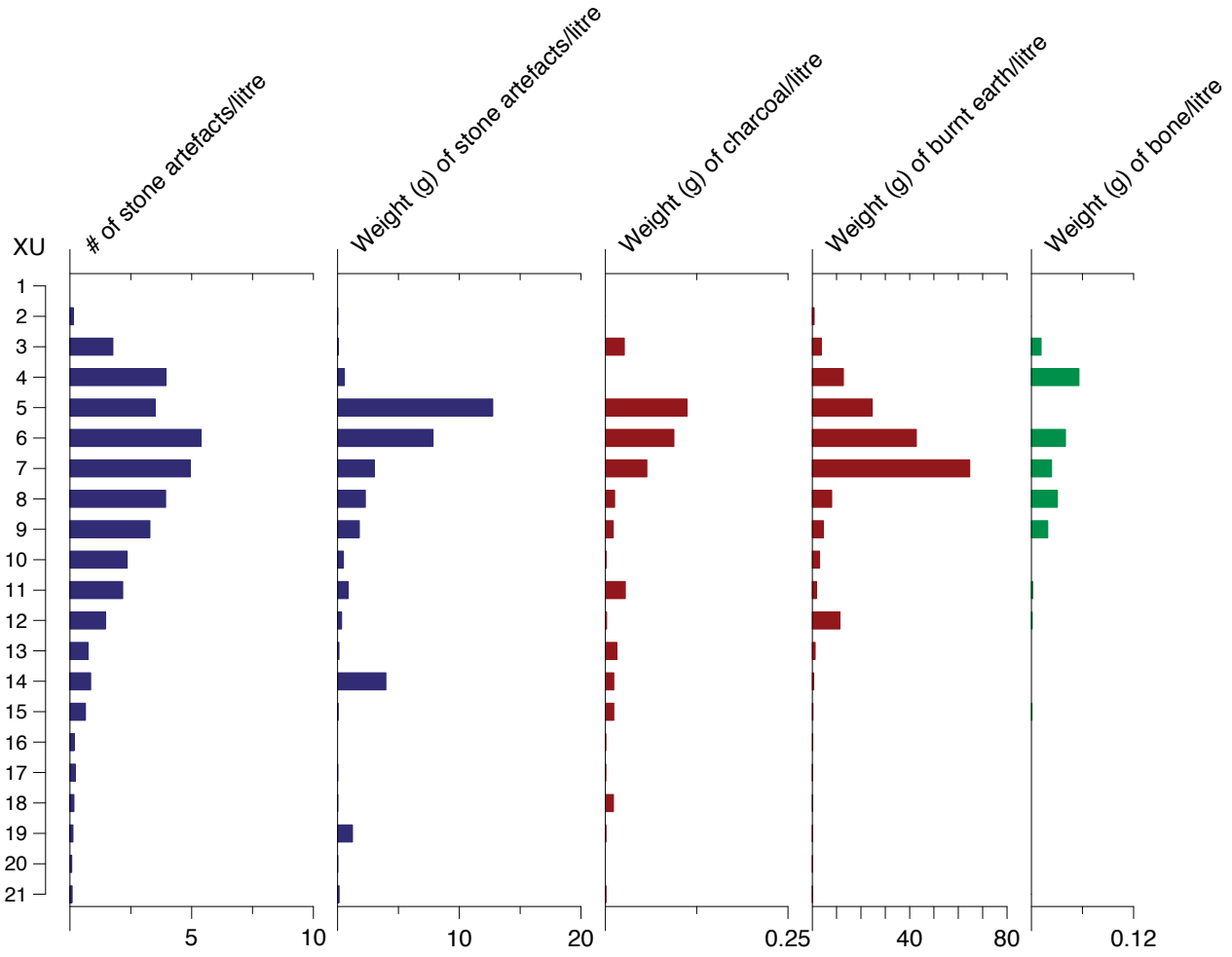

Figure 12 - Densities of excavated cultural materials per litre of excavated sediment, Waredaru Square $A$.

Figure 12 - Densités des matériaux culturels par litre de sédiments, Waredaru Carré $A$. susceptible to degradation following burial through microbial and fungal activity, whereas calcined bone (in which all organic matter has been incinerated) is much less so. These taphonomic processes working in combination could account for the character of the Waredaru assemblage. However, an alternative interpretation is that the intensely calcined condition of the small assemblage is due to its origin from a fireplace, as suggested above.

Today, as may be inferred for the past, bones of consumed animals along with other food scraps are often discarded into fireplaces where they are subject to repeated firing. Figure 15 shows a modern sample of this kind, collected by KA in 2013 from a contemporary fireplace in a garden hut in the Upper Strickland River. In this sample, the bulk of the bone (probably more than $90 \%$ ) is calcined and highly fragmented. However, it is otherwise in good condition. Large quantities of burnt clay-rich soil and charcoal are also present in this sample, as in the archaeological assemblages from Waredaru.

In reality both factors are probably responsible for the character of the Waredaru bone assemblage. The sequence of behavioural and taphonomic events that we envisage involves people walking a short distance from their longhouses to dump piles of ash, charcoal, fired clay and bones derived from their fire pits; this material becoming buried in leaf litter and eventually by soil; microbial activity working rapidly to break down any bone containing residual organic components; and percolating rainwater and fluctuating groundwater working to slowly dissolve the inorganic or mineral components of the bone, including that of the calcined bone. Just how much of an original assemblage has been lost through the combined action of the post-depositional processes is difficult to estimate, as it depends on the original proportion of calcined to unburnt/lightly burnt remains, as well as on the rate of degradation. However, the taxonomic diversity observed within the tiny Waredaru assemblage (fish, a python and some mammals) provides a further clue that a substantial proportion of the original assemblage has indeed been lost.

\section{The stone artefacts}

\section{Square $\boldsymbol{A}$}

A total of 600 stone artefacts weighing $490.0 \mathrm{~g}$ were recovered from Square $A$. These are generally small, averaging $9.1 \mathrm{~mm}$ in maximum length with most artefacts measuring 5.0-10.0 mm long. Individual artefacts weigh from $<0.01 \mathrm{~g}$ to $71.9 \mathrm{~g}$, with a mean weight of $1.0 \mathrm{~g}$ for the assemblage as a whole. The vertical distribution of stone artefacts and other cultural materials, radiocarbon dates and stratigraphic evidence (see fig. 12 above) each suggests a single major period of occupation focused on XU3-XU9. A peak in stone artefact weights in XU6 is largely due to the presence of some large flakes, whereas the isolated peak in XU14 is due to a single axe/adze fragment weighing $71.9 \mathrm{~g}$. Because the entire assemblage arguably dates to a single occupational phase of limited duration without significant variation between XUs, the sum 


\begin{tabular}{|c|c|c|c|c|c|c|c|c|c|}
\hline XU & $\begin{array}{l}\text { Depth } \\
(\mathrm{cm})\end{array}$ & su & $\begin{array}{l}\text { Wk- Laboratory } \\
\text { Code }\end{array}$ & $\delta^{13} \mathrm{C} \%$ & $\begin{array}{l}\text { \% Modern } \\
\text { Carbon } \\
\left(\mathrm{F}^{14} \mathrm{C} \%\right)\end{array}$ & $\begin{array}{c}{ }^{14} \mathrm{C} \text { Age } \\
\text { (years BP) }\end{array}$ & $\begin{array}{l}\text { Unmodelled } \\
\text { Calibrated Age BP } \\
\text { (68.2\% probability) }\end{array}$ & $\begin{array}{c}\text { Unmodelled } \\
\text { Calibrated Age BP } \\
\text { (95.4\% probability) }\end{array}$ & $\begin{array}{c}\text { Median } \\
\text { Calibrated Age } \\
\text { BP }\end{array}$ \\
\hline \multicolumn{10}{|c|}{ Square $\mathrm{A}$} \\
\hline 3 & $2.4-5.9$ & $1 \mathrm{c}$ & 37605 & $-27.1 \pm 0.2$ & $97.4 \pm 0.2$ & $214 \pm 20$ & $\begin{array}{c}0-6 \\
152-170 \\
281-296\end{array}$ & $\begin{array}{c}0-13 \\
149-188 \\
270-303\end{array}$ & 168 \\
\hline 5 & $8.9-9.3$ & $1 c+1 d$ & 37606 & $-27.2 \pm 0.2$ & $97.4 \pm 0.2$ & $212 \pm 20$ & $\begin{array}{c}0-6 \\
152-170 \\
281-295 \\
\end{array}$ & $\begin{array}{c}0-13 \\
149-188 \\
270-303 \\
\end{array}$ & 168 \\
\hline 7 & $11.6-13.2$ & $1 d$ & 37607 & $-26.3 \pm 0.2$ & $97.7 \pm 0.2$ & $183 \pm 20$ & $\begin{array}{c}0-13 \\
148-152 \\
168-188 \\
200-212 \\
269-283\end{array}$ & $\begin{array}{c}-0-22 \\
143-218 \\
266-287\end{array}$ & 181 \\
\hline 9 & 15.9 & $1 \mathrm{~d}$ & 25302 & $-29.1 \pm 0.2$ & $97.2 \pm 0.2$ & $227 \pm 30$ & $\begin{array}{c}0-7 \\
152-171 \\
281-305\end{array}$ & $\begin{array}{c}0-18 \\
145-215 \\
267-312\end{array}$ & 199 \\
\hline 11 & $17.8-19.4$ & $1 d+2$ & 37608 & $-28.2 \pm 0.2$ & $97.9 \pm 0.2$ & $169 \pm 20$ & $\begin{array}{c}7-16 \\
145-152 \\
171-214 \\
268-281 \\
\end{array}$ & $\begin{array}{c}0-32 \\
137-158 \\
165-224 \\
257-285\end{array}$ & 185 \\
\hline 13 & 23.1 & $1 d+2$ & 25303 & $-27.5 \pm 0.2$ & $97.0 \pm 0.3$ & $249 \pm 30$ & $\begin{array}{l}153-169 \\
282-312\end{array}$ & $\begin{array}{c}0-12 \\
149-187 \\
270-325 \\
376-429\end{array}$ & 294 \\
\hline $21 \mathrm{~b}$ & 38.2 & $1 d+2$ & 37611 & measured & $96.8 \pm 0.3$ & $258 \pm 21$ & $\begin{array}{l}159-162 \\
286-310\end{array}$ & $\begin{array}{l}153-168 \\
282-317 \\
400-423\end{array}$ & 300 \\
\hline 15 & $24.4-26.8$ & $1 d+2$ & 37609 & $-27.3 \pm 0.2$ & $84.7 \pm 0.2$ & $1331 \pm 20$ & $1269-1292$ & $\begin{array}{l}1187-1204 \\
1240-1300 \\
\end{array}$ & 1279 \\
\hline 18 & $30.6-32.1$ & $1 d+2$ & 37610 & $-26.9 \pm 0.2$ & $84.7 \pm 0.2$ & $1334 \pm 21$ & 1269-1293 & $\begin{array}{l}1187-1204 \\
1240-1301\end{array}$ & 1280 \\
\hline \multicolumn{10}{|c|}{ Square B } \\
\hline 3 & $4.4-6.6$ & $1 d$ & 37612 & $-25.3 \pm 0.2$ & $70.1 \pm 0.2$ & $2851 \pm 20$ & 2927-2997 & $\begin{array}{l}2880-3037 \\
3051-3056\end{array}$ & 2960 \\
\hline
\end{tabular}

Table 5 - Radiocarbon determinations, Waredaru. All 14C ages are AMS on single pieces of charcoal. Calibrations undertaken using OxCal v4.2 (IntCal13) (Reimer et al. 2013).

Tableau 5 - Datation au 14C, Waredaru Carré A. Toutes les datations au 14C utilisent la méthode AMS sur échantillons uniques de charbons de bois. Les calibrations ont été effectuées avec le programme OxCal v4.2 (IntCal13) (Reimer et al. 2013).

\begin{tabular}{|c|c|c|c|c|c|}
\hline \multirow{2}{*}{$\mathbf{X U}$} & \multirow{2}{*}{ SU } & Charcoal & Burnt Earth & \multicolumn{2}{|c|}{ Stone Artefacts } \\
\cline { 4 - 6 } & & $\mathbf{( g )}$ & $\mathbf{( g )}$ & $\mathbf{( \# )}$ & $\mathbf{( g )}$ \\
\hline 1 & $1 \mathrm{a}+1 \mathrm{~b}+1 \mathrm{c}$ & & & 5 & 25.6 \\
\hline 2 & $1 \mathrm{c}+1 \mathrm{~d}$ & & & 213 & 79.6 \\
\hline 3 & $1 \mathrm{~d}$ & 0.02 & 0.56 & 197 & 69.7 \\
\hline 4 & $1 \mathrm{~d}$ & & & 127 & 20.4 \\
\hline 5 & $1 \mathrm{~d}+2$ & & & 66 & 3.7 \\
\hline 6 & $1 \mathrm{~d}+2$ & & & 41 & 3.1 \\
\hline 7 & $1 \mathrm{~d}+2$ & & & 18 & 0.9 \\
\hline 8 & $1 \mathrm{~d}+2$ & & & 17 & 1.9 \\
\hline 9 & $1 \mathrm{~d}+2$ & & & 5 & 0.2 \\
\hline 10 & $1 \mathrm{~d}+2$ & & & 4 & 0.1 \\
\hline 11 & $1 \mathrm{~d}+2$ & & & 3 & 0.1 \\
\hline 12 & $1 \mathrm{~d}+2$ & & & 6 & 0.4 \\
\hline 13 & $1 \mathrm{~d}+2$ & & & 2 & 0.1 \\
\hline 14 & 2 & & & 1 & $<0.1$ \\
\hline 15 & 2 & & & 3 & 0.2 \\
\hline 16 & 2 & & 0.30 & 3 & 0.1 \\
\hline 17 & 2 & & 0.04 & 2 & $<0.1$ \\
\hline 18 & 2 & & & & \\
\hline Total & & $\mathbf{0 . 0 2}$ & $\mathbf{0 . 5 6}$ & $\mathbf{7 1 3}$ & $\mathbf{2 0 6 . 1}$ \\
\hline
\end{tabular}

Table 6 - Cultural contents, Waredaru Square B.

Tableau 6 - Contenu culturel, Waredaru Carré B.

\begin{tabular}{|c|c|c|c|c|c|c|}
\hline \multirow{2}{*}{$\mathbf{X U}$} & \multirow{2}{*}{$\mathbf{S U}$} & Fish & Snake & Mammal & Unidentified & Total \\
\hline & & $\mathbf{( g )}$ & $\mathbf{( g )}$ & $\mathbf{( g )}$ & $\mathbf{( g )}$ & $\mathbf{( g )}$ \\
\hline 1 & $1 \mathrm{a}$ & & & & & \\
\hline 2 & $1 \mathrm{~b}+1 \mathrm{c}$ & & & & & \\
\hline 3 & $1 \mathrm{c}$ & & & & 0.29 & 0.29 \\
\hline 4 & $1 \mathrm{c}+1 \mathrm{~d}$ & 0.17 & 0.33 & 0.60 & 0.13 & 1.23 \\
\hline 5 & $1 \mathrm{c}+1 \mathrm{~d}$ & & & & & \\
\hline 6 & $1 \mathrm{~d}$ & 0.52 & & & 0.20 & 0.72 \\
\hline 7 & $1 \mathrm{~d}$ & & & & 0.45 & 0.45 \\
\hline 8 & $1 \mathrm{~d}$ & 0.08 & & 0.32 & 0.06 & 0.46 \\
\hline 9 & $1 \mathrm{~d}$ & & & & 0.27 & 0.27 \\
\hline 10 & $1 \mathrm{~d}+2$ & & & & & \\
\hline 11 & $1 \mathrm{~d}+2$ & & & & 0.03 & 0.03 \\
\hline 12 & $1 \mathrm{~d}+2$ & & & & 0.02 & 0.02 \\
\hline 13 & $1 \mathrm{~d}+2$ & & & & & \\
\hline 14 & $1 \mathrm{~d}+2$ & & & & & \\
\hline 15 & $1 \mathrm{~d}+2$ & & & & 0.02 & 0.02 \\
\hline 16 & $1 \mathrm{~d}+2$ & & & & & \\
\hline 17 & $1 \mathrm{~d}+2$ & & & & & \\
\hline 18 & $1 \mathrm{~d}+2$ & & & & & \\
\hline 19 & $1 \mathrm{~d}+2$ & & & & & \\
\hline 20 & $1 \mathrm{~d}+2$ & & & & & \\
\hline $21 \mathrm{a}$ & $1 \mathrm{~d}+2$ & & & & & \\
\hline $21 \mathrm{~b}$ & $1 \mathrm{~d}+2$ & & & & & \\
\hline $21 \mathrm{c}$ & $1 \mathrm{~d}+2$ & & & & & \\
\hline Total & & $\mathbf{0 . 7 7}$ & $\mathbf{0 . 3 3}$ & $\mathbf{0 . 9 2}$ & $\mathbf{2 . 5 7}$ & $\mathbf{3 . 4 9}$ \\
\hline
\end{tabular}

Table 7 - Taxonomic composition of the animal bone, Waredaru Square $A$.

Tableau 7 - Composition taxonomique des ossements animaux, Waredaru Carré A. 


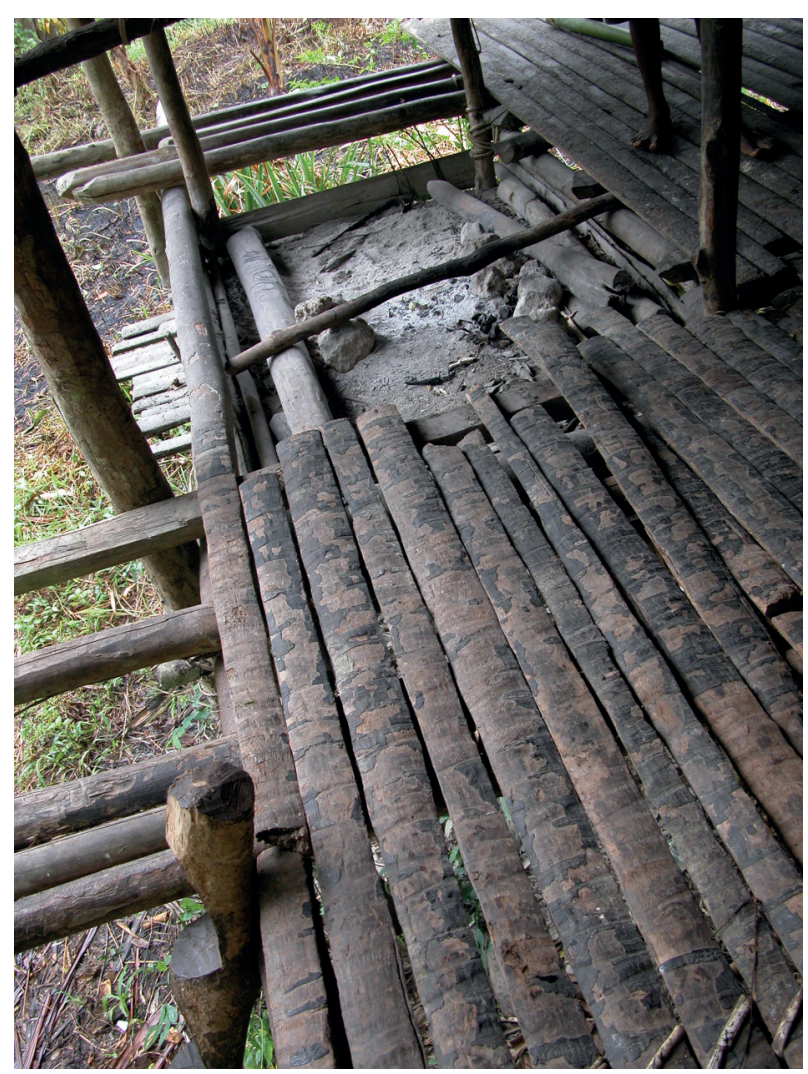

Figure 13 - Typical clay-lined fireplace within mid-Kikori River region stilt house, 2005 (photograph: Bruno David).

Figure 13 - Foyer typique en argile dans une maison sur pilotis de la région du cours moyen de la rivière Kikori (photographie : Bruno David).

of artefacts from Square $\mathrm{A}$ are analysed as a single assemblage. The one exception is the XU14 igneous axe/adze fragment that could belong to either one of the two occupational phases of Square A; it has been analysed separately. However, this elongated artefact was buried in a vertical position (fig. 16) - one of only three artefacts in the entire assemblage to lie vertically, the other two being much smaller (the vast majority of artefacts lying horizontally flat) - meaning that to hold itself in place it had to be placed in the ground with sediment already accumulated around it (i.e. the axe/adze fragment dates not to the age of its base, but rather to the age of its mid or upper levels, i.e. it is contemporaneous with the upper horizon of peak cultural deposit).

\section{Square $B$}

A total of 713 stone artefacts weighing $206.1 \mathrm{~g}$ were recovered from Square B. All are made of chert. Like Square A, artefacts are generally small, averaging $8.5 \mathrm{~mm}$ long (range: $2.0-48.1 \mathrm{~mm}$ ) with the majority measuring $5.0-10.0 \mathrm{~mm}$ in length. Their weights range from $<0.01 \mathrm{~g}$ to $15.8 \mathrm{~g}$ (average $=0.4 \mathrm{~g}$ ). Most artefacts come from XU2-XU4, although they are found in all XUs from XU1 to XU17 (see fig. 14 above).

\section{Raw Materials}

Chert sources are not found locally at the site, but nodules are easily extracted from limestone outcrops at Fakaiku (fig. 17), Tabakaroe (fig. 18) and other nearby source locations such as Avatie and Foro beginning one hour or $1.7 \mathrm{~km}$ to the south and southwest of Waredaru by foot (other sources of chert along this same limestone ridge over $80 \mathrm{~m}$ above sea level, and further inland, also occur on other nearby clan lands, such as the Seinkiri source of the Kesele clan to the west) (throughout this paper, we use the term 'nodule' only to refer to an unworked, generally rounded lump of chert that includes its cortex). These nodules are typically of an irregular oblong shape and typically $10-15 \mathrm{~cm}$ wide by $20-30 \mathrm{~cm}$ long. Imported chert sago-pounders originating from these sources (together referred to as 'the Baina quarries', after the present-day large, multi-clan village of Baina nearby) were documented along mid-Kikori River archaeological and village sites during ethnoarchaeological research undertaken by Jim Rhoads in the 1970s (Rhoads 1980). The closest source of igneous rock can be found in the Highlands a few tens of kilometres to the north and east, although long-distance trade of igneous stone axe/adzes has been well documented for many parts of the large continental island of New Guinea (e.g. Burton 1984; Pétrequin and Pétrequin 2000; Rhoads 2010; Rhoads and Mackenzie 1991).

Two different types of raw material occur in Square A: chert $(\#=597$, weight $=378.2 \mathrm{~g})$ and igneous rock $(\#=3$, weight $=111.8 \mathrm{~g}$ ). Chert is by far predominant, accounting for 597 of the 600 artefacts in Square A and all 713 artefacts from Square B.

\section{Chert Fracture Types}

The Square A chert artefacts are generally small, averaging $0.8 \mathrm{~g}$ in weight and $8.2 \mathrm{~mm}$ in length. They are on the whole highly fragmented, with $81.8 \%$ consisting of broken flakes, $9.2 \%$ complete flakes and $8.0 \%$ flaked pieces. The Square B artefacts show a very similar pattern, with $90.3 \%$ of the assemblage consisting of broken flakes, $6.0 \%$ complete flakes and 3.6\% flaked pieces (tabl. 8).

\section{Taphonomy of Chert Artefacts}

The colour of each chert artefact was recorded using the Geological Rock-Colour Chart from Munsell ${ }^{\circledR}$ Colour. Five colour values were identified (tabl. 9). Colour value \#3 predominates in Square A, accounting for $45.0 \%$ of the chert artefacts $(76.2 \%$ by weight). Crazing and/or potlid scars occur on $9.9 \%$ of Square A chert artefacts, most $(89.8 \%)$ being on artefacts of colour value \#3; potlid scars here represent $22.9 \%$ of colour value \#3 artefacts. 

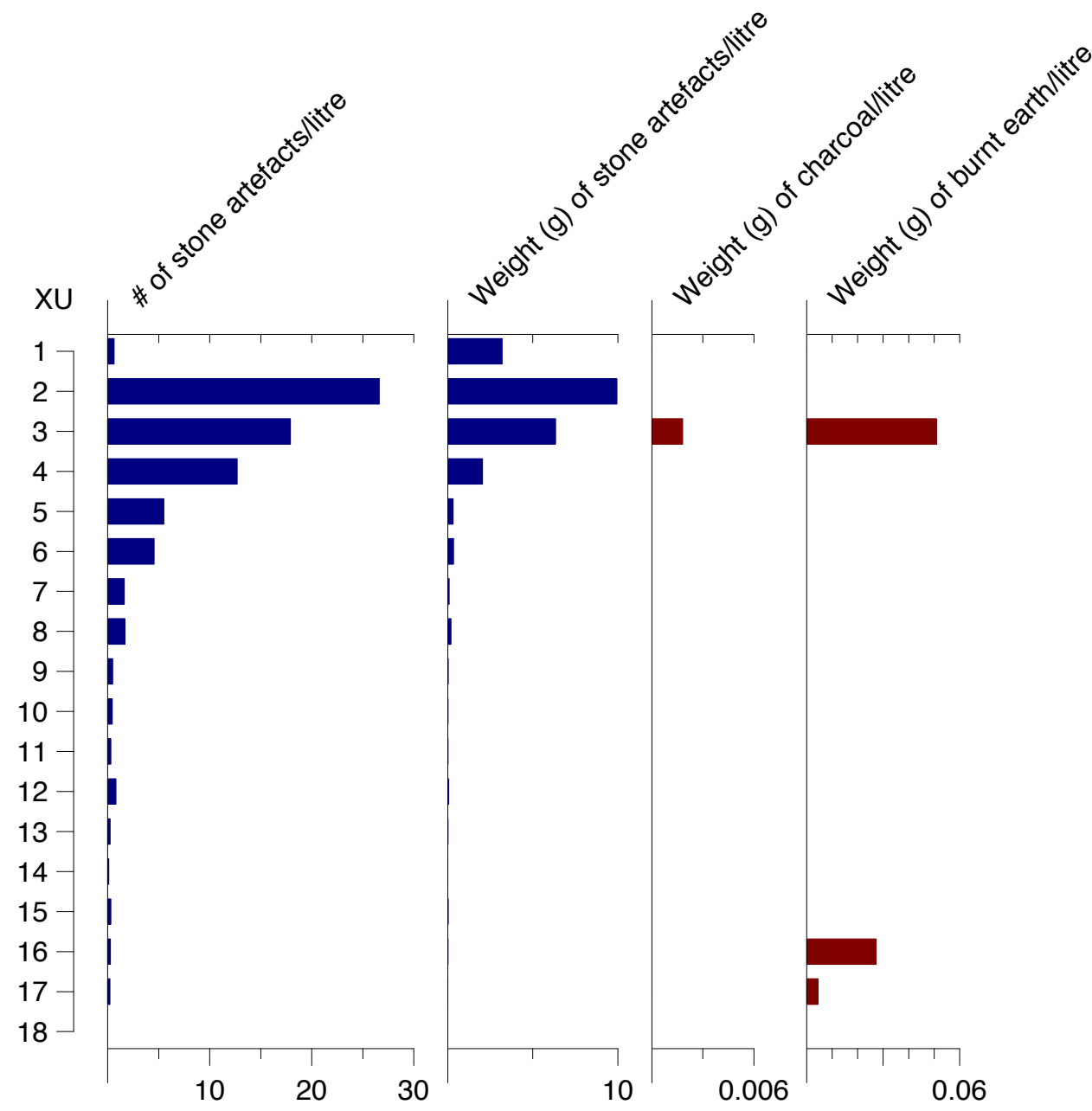

Figure 14 - Densities of excavated cultural materials per litre of excavated sediment, Waredaru Square B.

Figure 14 - Densités des matériaux culturels par litre de sédiments, Waredaru Carré B.

\begin{tabular}{|c|c|c|c|c|}
\hline \multirow{2}{*}{ Fracture type } & \multicolumn{2}{|c|}{ Square A } & \multicolumn{2}{c|}{ Square B } \\
\cline { 2 - 5 } & $\#$ & $\mathbf{\%}$ & $\#$ & $\%$ \\
\hline Broken flakes (other) & 299 & 50.1 & 388 & 54.4 \\
\hline Complete flake & 55 & 9.2 & 43 & 6.0 \\
\hline Flaked piece & 48 & 8.0 & 26 & 3.6 \\
\hline Proximal flake & 76 & 12.7 & 96 & 13.5 \\
\hline Medial flake & 66 & 11.1 & 118 & 16.5 \\
\hline Distal flake & 44 & 7.4 & 38 & 5.3 \\
\hline Potlid & 6 & 1.0 & 2 & 0.3 \\
\hline Right split cone & 1 & 0.2 & 2 & 0.3 \\
\hline Left split cone & 2 & 0.3 & 2 & 0.3 \\
\hline Total & $\mathbf{5 9 7}$ & $\mathbf{1 0 0}$ & $\mathbf{7 1 3}$ & $\mathbf{1 0 0}$ \\
\hline
\end{tabular}

Table 8 - Chert fracture type proportions.

Tableau 8 - Décompte et proportion du matériel en silex par type de fractures.
The fact that potlid scars were mainly found on both dorsal and ventral flake surfaces $(77.8 \%)$ confirms that heat application was not intentional, taking place after rather than before flake manufacture (Mercieca 2000). All potlids $(n=6)$ were also of colour value \#3. Given these patterns, it is possible that colour value \#3 is a product of heat alteration of artefact surfaces (we distinguish heat 'alteration' from controlled heat 'treatment', with the former referring to stone that has been heated after the manufacturing process (e.g. by discarding a stone in a fire), the latter during. Chert artefacts with potlid scars and/or crazing were found in high proportions from XU4 to XU14 in Square A. Here the majority of potlids were found in XU4 $(n=4)$, while the remaining two potlids were found in XU7 and XU14.

A different but comparable colour distribution occurs in Square B (tabl. 9), where colour value \#6 accounts for $77.4 \%$ of the assemblage by number and $65.8 \%$ by weight. Crazing and/or potlid scars occur on $2.9 \%$ of artefacts, with the majority being on chert of colour values 

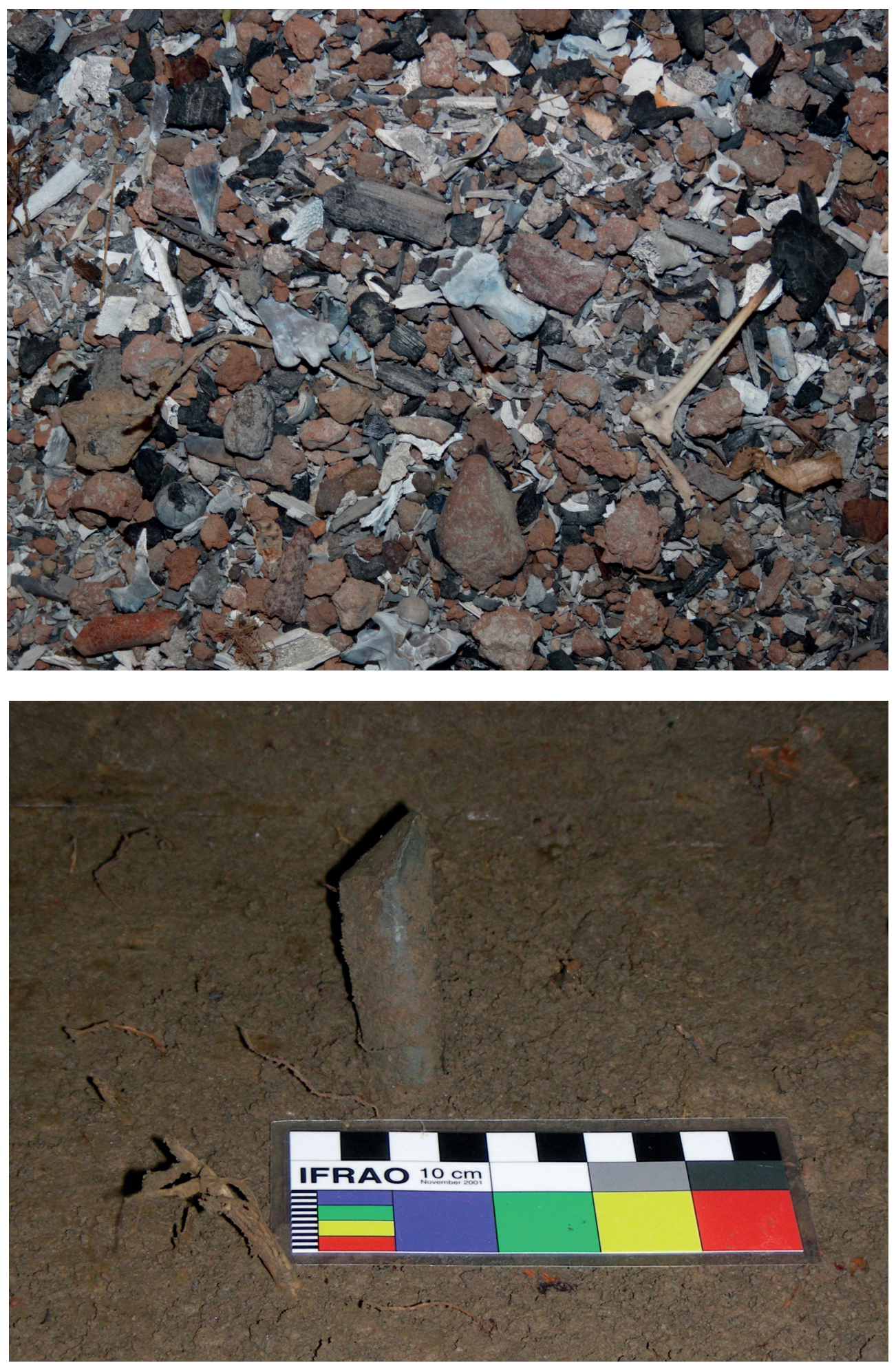

Figure 15 - Contents of a contemporary fireplace from a garden hut in the Upper Strickland River. Large quantities of burnt clay-rich soil and charcoal are present, along with abundant animal bone derived from fish, mammals, reptiles and birds. The bone is predominantly calcined as a consequence of repeated firing but a smaller quantity $(<10 \%$ by weight) of unburnt and lightly burnt bone is also present (photograph: Ken Aplin).

Figure 15 - Contenu d'un foyer contemporain dans une hutte, cours supérieur de la rivière Strickland. De grandes quantités d'argile brûlé et de charbon y sont présentes, ainsi que de nombreux os d'animaux (poissons, mammifères, reptiles et oiseaux). Les os sont principalement calcinés en raison de cuissons répétées mais une petite quantité ( $<10 \%$ en poids) d'os non brûlés et légèrement brûlés est également présente (photographie : Ken Aplin).
Figure 16 - The ground axe/adze fragment whose base lay in XU14, Waredaru Square $A$ excavation in progress, as positioned in situ at base of XU13 (photograph: Bruno David).

Figure 16 - Fragment de hache/herminette polie dont la base repose dans XU14, Waredaru Carré $A$, fouille en cours (photographie : Bruno David).
\#6 and \#3. Again potlid scars occur on both dorsal and ventral flake surfaces on $70.6 \%$ of flakes, indicating the application of heat after rather than before flake manufacture. Chert artefacts exhibiting crazing and/or potlid scars were found in high proportions in XU3 and XU4, where most colour value \#3 chert artefacts occur.

\section{Reduction Intensity and the Production of Chert Flakes}

No cores were recovered from either square. All flakes were produced using unipolar freehand percussion. Hiscock (2002) provides a method for assessing the Minimum Number of Flakes (MNF) present in a stone 

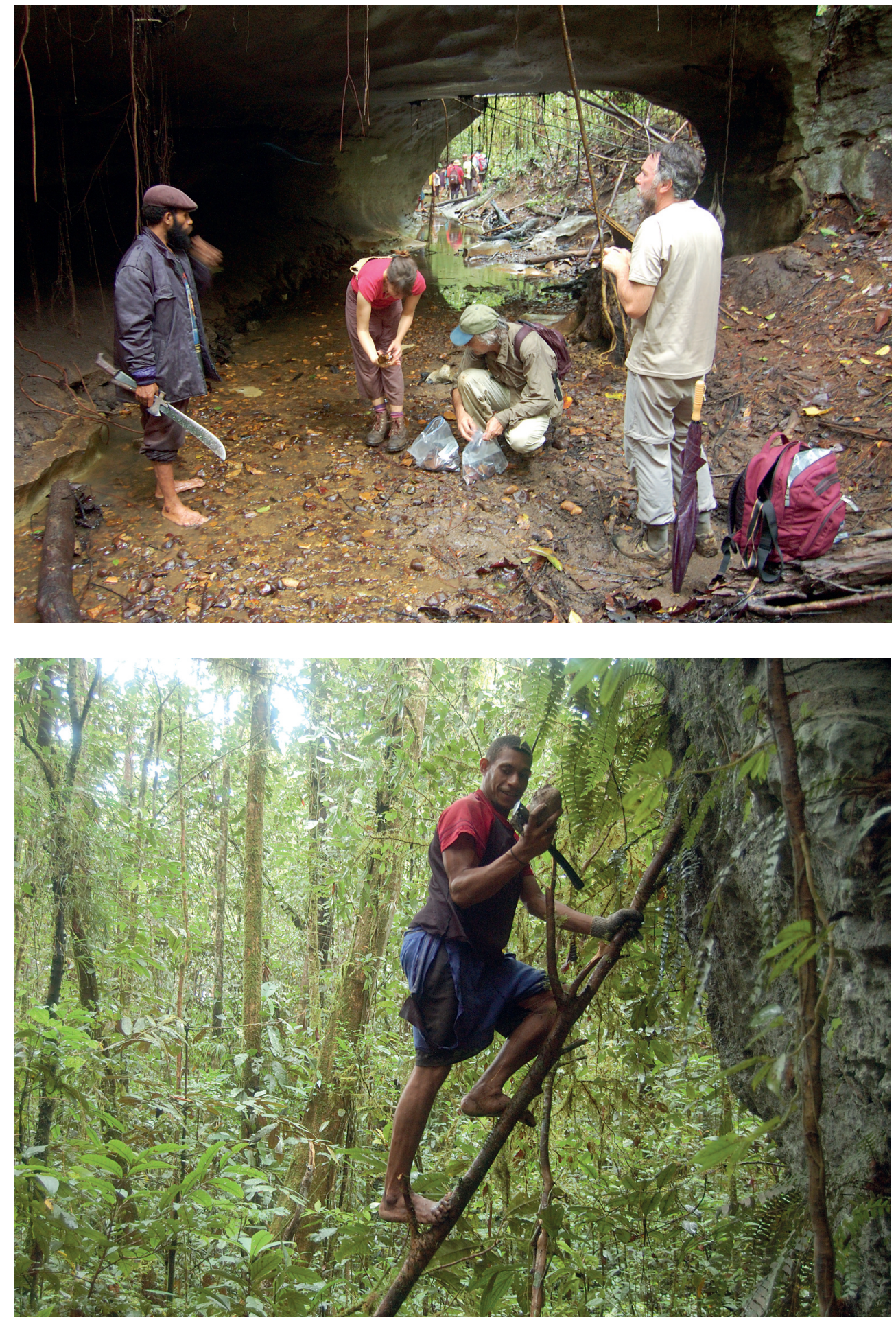

Figure 17 - The Fakaiku stone source, 2008 (photograph: Bruno David).

Figure 17 - La source de silex Fakaiku, 2008 (photographie : Bruno David).
Figure 18 - Extracting chert nodules from the Tabakaroe limestone outcrops, 2008 (photograph: Bruno David).

Figure 18 - Extraction de rognons de silex situés dans les affleurements calcaires de Tabakaroe, 2008 (photographie : Bruno David). artefact assemblage, enabling estimation of knapping intensities. A modified version of Hiscock's MNF calculation was separately calculated for each square using the following formula: $\mathrm{MNF}=\mathrm{C}+\mathrm{T}+\mathrm{CL}$, where $\mathrm{C}$ stands for the number of complete flakes, $T$ for the highest number of transversally broken flakes (either proximal or distal) and CL for the highest number of complete longitudinally broken flakes (either right or left). The MNF was calculated for each $\mathrm{XU}$ and then summed for each square. With a total MNF of 140 for Square A and 142 for Square B, several knapping events can be shown to have taken place in each square. Many cores 


\begin{tabular}{|c|c|c|c|c|c|c|c|c|c|c|c|}
\hline \multicolumn{9}{|c|}{ Colour } & \multicolumn{3}{c|}{ Square A } \\
\hline $\begin{array}{c}\text { Colour } \\
\text { value \# }\end{array}$ & Colour & $\begin{array}{c}\text { Munsell } \\
\text { colour code }\end{array}$ & $\begin{array}{c}\text { Munsell colour } \\
\text { name }\end{array}$ & $\#$ & $\#(\%)$ & $\begin{array}{c}\text { Weight } \\
(\mathbf{g})\end{array}$ & $\begin{array}{c}\text { Weight } \\
(\%)\end{array}$ & $\#$ & $\#(\%)$ & $\begin{array}{c}\text { Weight } \\
(\mathbf{g})\end{array}$ & $\begin{array}{c}\text { Weight } \\
(\%)\end{array}$ \\
\hline 2 & & $5 Y 8 / 1$ & Yellowish Grey & 23 & 3.9 & 0.4 & 0.1 & 64 & 9.0 & 2.6 & 1.3 \\
\hline 3 & N3 & Dark Grey & 269 & 45.0 & 288.2 & 76.2 & 39 & 5.5 & 43.0 & 20.9 \\
\hline 5 & & $\begin{array}{c}\text { 10YR 5/4 to } \\
\text { 10YR 4/2 }\end{array}$ & $\begin{array}{c}\text { Moderate Yellowish } \\
\text { Brown to Dark } \\
\text { Yellowish Brown }\end{array}$ & 110 & 18.5 & 47.9 & 12.6 & 58 & 8.1 & 24.9 & 12.1 \\
\hline 6 & 10YR 6/2 & $\begin{array}{c}\text { Pale Yellowish } \\
\text { Brown }\end{array}$ & 194 & 32.5 & 41.3 & 10.9 & 552 & 77.4 & 135.5 & 65.8 \\
\hline 9 & & 10R 2/2 & Very Dusky Red & 1 & 0.2 & 0.3 & 0.1 & & & & \\
\hline
\end{tabular}

Table 9 - Chert colour values and corresponding Munsell囚 Colour (Geological Rock-Colour Chart).

Tableau 9 - Couleur des silex et couleurs Munsell® (Geological Rock-Colour Chart) correspondantes.

were necessary to produce these MNF values. Since no cores were recovered from either square, the cores must have been transported elsewhere, either in unexhausted form to continue their reduction or as core-tools such as sago-pounders as suggested by oral traditions that identify Waredaru as a locale of specialised sago-pounder manufacture. In this region (and probably across Papua New Guinea wherever sago-pounders are manufactured), ethnographically the reduction of a chert nodule gives birth to a single sago-pounder only, the sago-pounder being the core that has been reduced through a number of more or less formal stages of reduction (for two local examples, see fig. 5 above). We note that in 2008 we systematically recorded Wero Sisira making a number of sago-pounders from Tabakaroe nodules; we are currently in the process of analysing their reduction sequences and will publish these results separately.

In the absence of cores, reduction intensity was evaluated via the number of scars present on the dorsal surfaces of complete flakes. In Square A the majority of complete flakes $(\#=24)$ display one to three dorsal scars. Flakes exhibiting one dorsal scar are the most common (\# =12). Seven complete flakes contain at least one scar from a direction other than from the proximal end, thus indicating that at least one core rotation took place before those flakes were removed from the core. The number of scars present on the dorsal surfaces of complete flakes, as well as the presence of scars originating from directions other than proximal, is strongly influenced by their dimensions. Not surprisingly, complete flakes with at least one dorsal scar are longer (mean: $24.3 \pm 14.5 \mathrm{~mm}$ ) than complete flakes without dorsal scars (mean: $10.9 \pm 14.1 \mathrm{~mm}$ ). Similarly, complete flakes signaling core rotation are longer (mean: $24.2 \pm$ $14.3 \mathrm{~mm}$ ) than those indicating no rotation (mean: $17.0 \pm$ $13.5 \mathrm{~mm}$ ). Redirecting flakes (flakes exhibiting the remnants of striking platforms on their dorsal surfaces) can also help quantify core rotation. Such artefacts were rare, being restricted to two instances near the top of Square A.
In Square B the pattern is similar, with 23 complete flakes having one dorsal scar or more. Flakes with one to three dorsal scars predominate $(\#=21)$. Only two flakes have more than three dorsal scars. When dorsal scars occur, the majority originated from the proximal end $(\#=18)$. Only five complete flakes exhibiting dorsal scars indicate at least one core rotation. A similar pattern to Square A regarding flake length and the presence/absence of flakes scars and core rotation was observed for Square $B$. The presence of one complete flake and one broken flake exhibiting respectively on their dorsal surface the remnants of one and two old platforms confirm the occurrence of up to two core rotations. The presence of flakes indicating a maximum of two core rotations suggests that small amounts of core rotation took place in the areas of Squares A and B. However, the small number of flakes indicating core rotation is likely at least in part conditioned by the size of the recovered flakes. For instance, the single flake displaying four scars of three different orientations in Square B has a length of $32.7 \mathrm{~mm}$, noticeably larger than most flakes. Flakes exhibiting at least one core rotation average $26.5 \mathrm{~mm}$ in Square B, while those indicating no core rotation are 10 $\mathrm{mm}$ shorter. As most complete flakes are shorter than 15 $\mathrm{mm}$ long, an absence of evidence for moderate degrees of core rotation is to be expected. Yet to what extent did core shapes and core dimensions condition the number of core rotations? In the absence of formal cores, some small flakes could have originated from the retouching of larger flakes.

\section{Cortex on Chert Artefacts}

Cortex occurs on $9.7 \%(\#=58)$ of chert artefacts in Square A and $8.3 \%(\#=59)$ in Square $B$, suggesting that main decortication procedures took place off-site, probably at the source in order to test raw material quality. Only one flake in Square B has cortex on its entire dorsal surface; its distal end has an outrepassé termination and, in the absence of cores, its length allows us to estimate original core dimensions. With an axial length of $31 \mathrm{~mm}$ and an axial 
width of $45 \mathrm{~mm}$, the core from which this flake originated was probably from a nodule measuring at least $50 \mathrm{~mm}$ in length or width. This accords well with the extrapolated nodule dimensions from a possible flake-core identified from Square A (see below).

\section{Complete Chert Flakes}

Mean measurements for cortical and non-cortical complete chert flakes are presented in Tables 10 and 11 respectively. Flakes less than $5 \mathrm{~mm}$ long and wide are excluded from these calculations. Cortical flakes are generally over $10 \mathrm{~mm}$ long and wide and over $5 \mathrm{~mm}$ thick in Square $A$, and over $20 \mathrm{~mm}$ long, $10 \mathrm{~mm}$ wide and $2.5 \mathrm{~mm}$ thick in Square B. Small amounts of cortex can remain on flakes during late stages of reduction, which would explain the recovery of small cortical flakes. The fact that in both squares cortical complete flakes are generally larger than non-cortical complete flakes is in accordance with general reduction models. In terms of shape, cortical and non-cortical complete flakes are rather squat in both Square $A$ (elongation value $=1.4$ ) and Square B (elongation value = 1.2) (fig. 19).

\section{Platforms on Chert Flakes}

Flat (single-flaked) platforms predominate in both squares (Square A: \# = 102; Square B: \# = 93), with a lower incidence of crushed platforms (Square A: \# = 12; Square B: \# = 17), multiple-flaked platforms (Square A: \# = 7; Square B: \# 20) and cortical platforms (Square B:
$\#=9$ ). Overhang removal was sometimes observed, being present on $26.6 \%$ of platforms $(\#=33)$ in Square $A$ and $33.6 \%(\#=41)$ in Square B and thus indicating that some platform preparation took place. Platforms are generally small, averaging $6.3 \pm 5.4 \mathrm{~mm}$ wide and $2.4 \pm$ $2.7 \mathrm{~mm}$ thick in Square $A$ and $4.8 \pm 2.9 \mathrm{~mm}$ wide and $1.4 \pm 0.8 \mathrm{~mm}$ thick in Square B.

\section{Terminations on Chert Flakes}

Feather terminations are the most common type of terminations (Square A: $\#=60$; Square B: $\#=44$ ), followed by hinge (Square A: \# = 31; Square B: \# = 31), step (Square A: \# = 8; Square B: \# =5) and outrepassé (Square A: \# = 2; Square B: \# =1). The fact that abrupt (step and hinge) terminations are found in high quantities (Square A: \# = 39; Square B: \# = 36) indicates that stone knappers experienced some problems which, following Hiscock (2007), relate to difficulties in preserving adequate core morphology during late reduction stages.

\section{Chert Implements}

A total of five chert flakes (two complete and three broken flakes) from Square $A$ and six from Square B (two complete and four broken flakes), representing $0.8 \%$ of the chert assemblage of each square, display signs of retouching. The size and shape of retouched complete flakes provide an idea of the type of flakes selected for retouching. Table 12 presents the dimensions and shapes of complete retouched flakes. Retouched

\begin{tabular}{|c|c|c|c|c|c|c|}
\hline \multirow{2}{*}{ Attribute } & \multicolumn{3}{|c|}{ Square A } & \multicolumn{3}{c|}{ Square B } \\
\cline { 2 - 7 } & Mean & Min. - Max. & $\#$ & Mean & Min. - Max. & $\#$ \\
\hline Weight $(\mathrm{g})$ & $4.4 \pm 5.4$ & $<0.1-16.7$ & 16 & $5.3 \pm 6.4$ & $0.1-15.8$ & 8 \\
\hline Length $(\mathrm{mm})$ & $21.5 \pm 12.7$ & $3.2-42.3$ & 16 & $27.3 \pm 11.9$ & $7.0-48.1$ & 8 \\
\hline Width $(\mathrm{mm})$ & $16.6 \pm 10.6$ & $5.3-41.4$ & 16 & $24.9 \pm 15.4$ & $6.8-50.3$ & 8 \\
\hline Thickness (mm) & $5.8 \pm 4.7$ & $0.8-14.8$ & 16 & $4.5 \pm 2.6$ & $1.1-9.6$ & 8 \\
\hline Elongation & $1.4 \pm 0.8$ & $0.4-3.5$ & 16 & $1.2 \pm 0.3$ & $0.7-1.7$ & 8 \\
\hline
\end{tabular}

Table 10 - Complete unretouched cortical chert flake weight, dimensions and elongation, excluding flakes $<5.0 \mathrm{~mm}$ long and wide.

Tableau 10 - Poids, dimensions et élongation des éclats corticaux entiers non retouchés, excluant ceux mesurant $<5.0 \mathrm{~mm}$ de long et de large.

\begin{tabular}{|c|c|c|c|c|c|c|}
\hline \multirow{2}{*}{ Attribute } & \multicolumn{3}{|c|}{ Square A } & \multicolumn{3}{c|}{ Square B } \\
\cline { 2 - 7 } & Mean & Min. - Max. & $\#$ & Mean & Min. - Max. & \# \\
\hline Weight $(\mathrm{g})$ & $1.8 \pm 3.8$ & $<0.1-16.5$ & 28 & $0.7 \pm 1.2$ & $<0.1-4.9$ & 26 \\
\hline Length $(\mathrm{mm})$ & $14.2 \pm 12.0$ & $4.6-44.2$ & 28 & $12.6 \pm 8.1$ & $3.9-35.2$ & 26 \\
\hline Width $(\mathrm{mm})$ & $11.5 \pm 8.5$ & $2.7-36.6$ & 28 & $11.8 \pm 7.3$ & $3.3-29.9$ & 26 \\
\hline Thickness $(\mathrm{mm})$ & $2.8 \pm 3.1$ & $0.5-12.6$ & 28 & $2.2 \pm 1.6$ & $0.6-7.6$ & 26 \\
\hline Elongation & $1.3 \pm 0.7$ & $0.6-4.1$ & 28 & $1.2 \pm 0.52$ & $0.6-2.5$ & 26 \\
\hline
\end{tabular}

Table 11 - Complete unretouched non-cortical chert flake weight, dimensions and elongation, excluding flakes $<5.0 \mathrm{~mm}$ long and wide.

Tableau 11 - Poids, dimensions et élongation des éclats entiers non retouchés et non corticaux, excluant ceux mesurant $<5.0 \mathrm{~mm}$ de long et de large. 
A

B

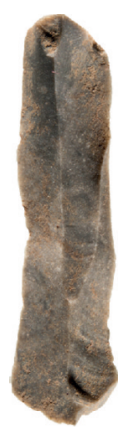

C

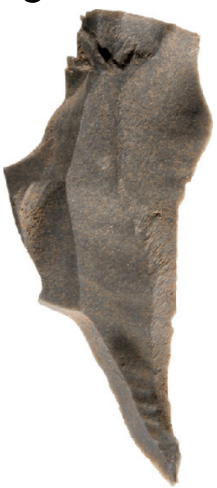

D

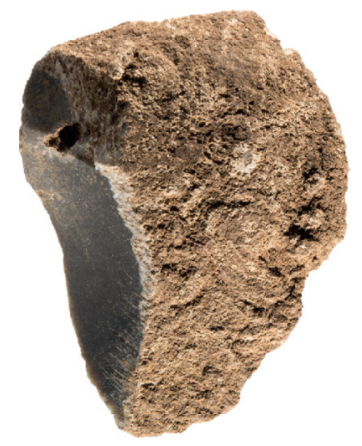

E

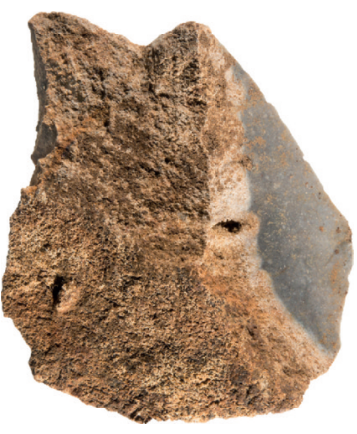

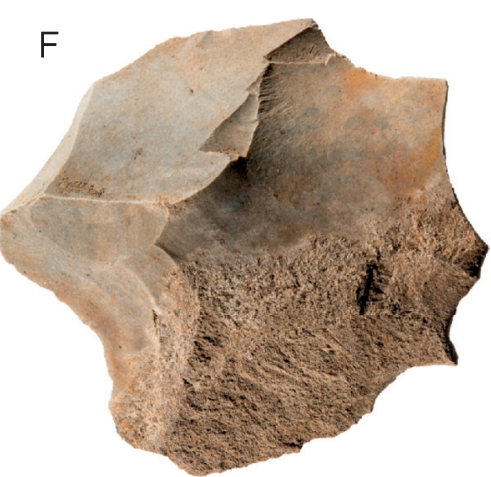

G

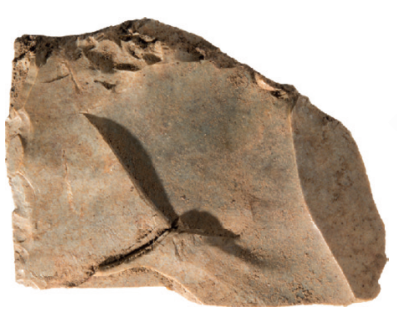

$\mathrm{J}$

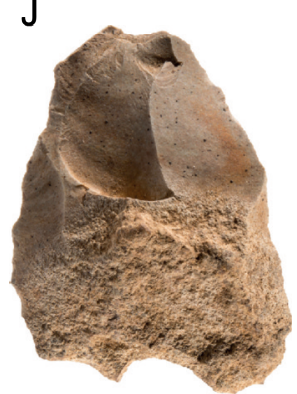

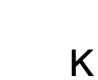

(1)
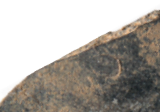
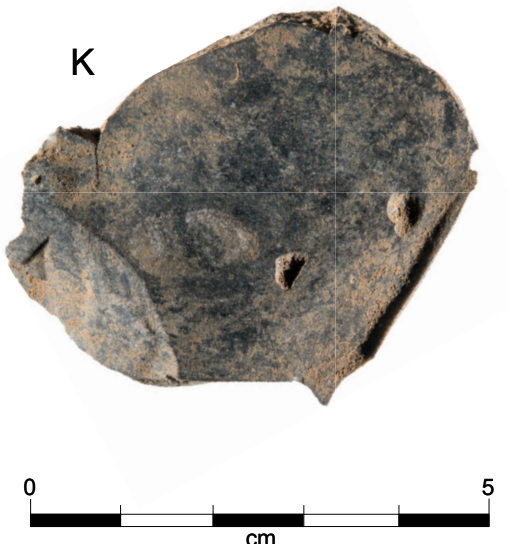

$\mathrm{H}$

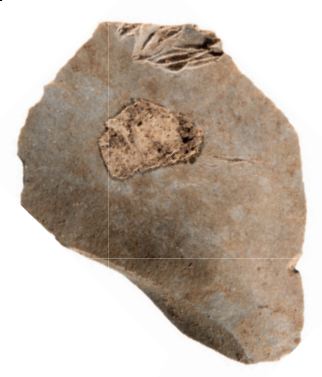

I
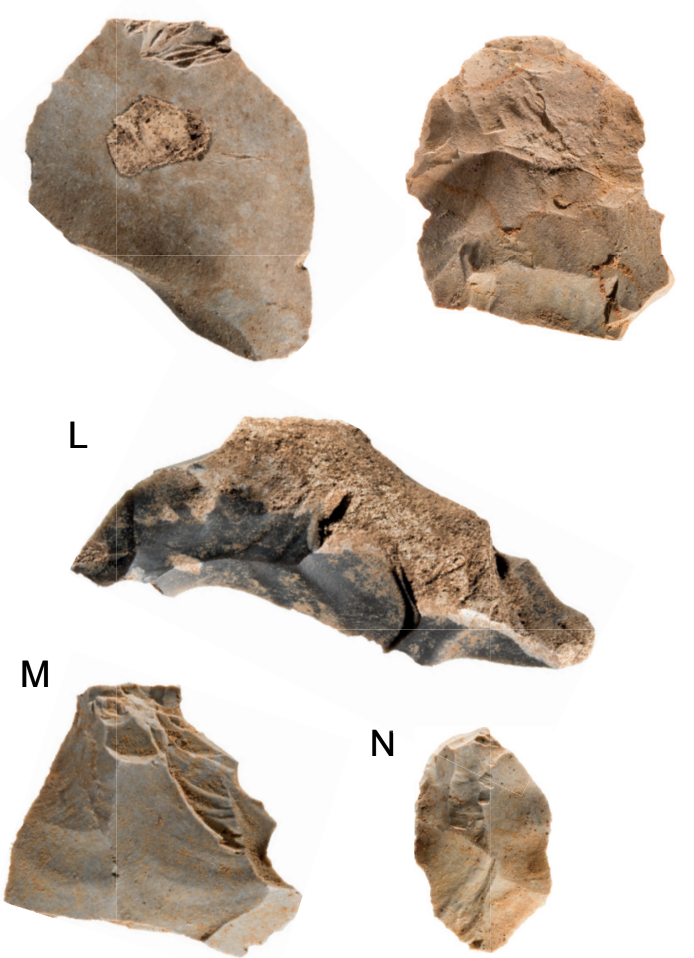

$\mathrm{N}$

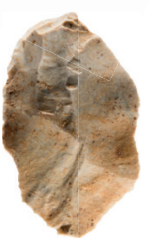

Figure 19 - Excavated chert artefacts from Waredaru. Unretouched flakes $(A-C, G-I, K, M, N)$; cortical flakes $(D-F, J, L)$.

Figure 19 - Éclats de débitage, Waredaru. Éclats non retouchés ( $A-C, G-I, K, M, N)$; éclats corticaux (D - F, J, L).

complete flakes are generally much larger than unretouched ones. All Square A retouched artefacts exhibit some unipolar abrupt retouch. Retouching is generally on dorsal $(\#=4)$ rather than ventral $(\#=1)$ surfaces and along lateral $(\#=3)$, distal $(\#=1)$ or both proximal and distal margins $(\#=1)$. In Square $B$, retouching is mostly fine $(\#=3)$ or abrupt $(\#=2)$, occurring on dorsal $(\#=3)$, ventral $(\#=2)$ or both $(\#=1$ ) surfaces; here only lateral margins are retouched.
One thick flake exhibiting some abrupt retouching along its lateral left margin from Square A could have been used as a core. A series of three or four flakes were removed by using the ventral surface as a striking platform. Whether this represents an attempt at retouching the margin, or to produce small flakes or a combination of the two is uncertain. These flake scars, averaging $8.6 \mathrm{~mm}$ in length by $8.5 \mathrm{~mm}$ in width, are well within the range of the unretouched complete flake 
dimensions from Squares $A$ and B. This flake-core measures $50 \mathrm{~mm}$ long by $33 \mathrm{~mm}$ wide and $20 \mathrm{~mm}$ thick, with cortex covering $\sim 80 \%$ of the dorsal surface (fig. 20F). The fact that cortex nearly covered the entire dorsal surface apart for the retouched area/flake scars suggests that it was a primary reduction flake. Since part of its flat platform also displayed some cortex, the initial size of the chert nodule can be extrapolated from the maximum dimension of the flake to have been greater than $50 \mathrm{~mm}$. It appears that access to the chert source was not problematic, given an absence of further reduction via bipolar percussion.

In terms of formal implements, two flakes from Square B each display a notch on one of its lateral margins (fig. 20C, 20D). These artefacts morphologically resemble what Keipte Kuyumen clan members identify as a sawaka, being a stone tool type "used for shaping the cane used to make bow strings and to make rope" (Wero Sisira, Keipte Kuyumen master stone tool maker, personal communication 2009).

\section{The Igneous Artefacts}

Three artefacts made of fine-grained igneous rock were excavated from Square A. One plano-convex axe/adze (in Keipte: mivonhauma) fragment weighing $71.9 \mathrm{~g}$ was recovered from XU14 (fig. 20A). This axe/adze was first flaked to shape and then ground and polished. One small medial flake weighing $0.1 \mathrm{~g}$ came from XU9. A hammerstone (in Keipte: kivo kam) from XU5 in Square A weighs $39.8 \mathrm{~g}$ and measures $74 \mathrm{~mm}$ long by $26 \mathrm{~mm}$ wide (fig. 20B). Impact damage is apparent on both extremities. Its presence suggests on-site manufacturing activities.

\section{Discussion}

With a total of 1313 stone artefacts recovered from Squares $A$ and $B$, the Waredaru lithic assemblage is dominated by broken flakes and flaked pieces. Retouched flakes, potlids, and an axe/adze fragment and a hammerstone both made from fine-grained igneous material make up the rest of the assemblage. A striking feature of the assemblage is the high degree of similarity of variables relating to artefact manufacture across both squares, implying the use of a highly standardised reduction technology (consistent with the systematic manufacture of sago-pounders for domestic use and trade). Heat alteration on chert was common, with the majority of chert artefacts exhibiting crazing and/or potlid scars in XU4-XU14 in Square A and XU3-XU4 in Square $B$. The shallower depth of the heat-altered artefacts in Square B is due to the deflated surface of that part of the site, where a lag deposit is evident in the upper levels.

Cortex on chert is not common in either square. This paucity of cortex may be due to the small size of most artefacts (most artefacts are $<10 \mathrm{~mm}$ long), with cortex being more common on flakes measuring greater than 20 $\mathrm{mm}$ long; or to the initial removal of cortex elsewhere, such as closer to the source.

The Waredaru stone artefact assemblage is also marked by an absence of cores from either square; a thick, retouched flake from Square A may have been used as a core. As this thick flake-core possesses a large cortical surface, the size of the chert nodule from which it originated must have been more than $50 \mathrm{~mm}$ long (and possibly considerably greater). If cores were brought to the site from the source, their absence at Waredaru suggests that either they were carried away from the site for future use after reduction; or that they were heavily reduced and/or burnt beyond recognition on-site. Yet in both excavation squares, there is only evidence of chert having been reduced by unipolar freehand percussion. Reduction intensity was moderate, with dorsal flake scars most commonly indicating no core rotation, a feature of the later stages of local ethnographic sago-pounder manufacture (Bruno David, personal observation 2009). Only one flake exhibits evidence of two core rotations. While one to two core rotations could be associated with expedient modes of reduction, the significance of such reduction strategies would depend on the initial size of the core. If chert nodules measured greater than $50 \mathrm{~mm}$ in maximum dimension, one to two core rotations - i.e. the use of up to three striking platforms - would implicate a fairly extensive degree of reduction. Such a reduction strategy is not surprising, since stone is entirely absent in the site's vicinity (but present within approximately an hour's walk). Indicative of considerable reduction, complete flakes were generally small (mean length: $13.4 \pm 10.0 \mathrm{~mm}$ ) and squat (mean elongation: $1.3 \pm 0.5$ ). Platforms were also small (mean width: $5.6 \pm 4.2 \mathrm{~mm}$; mean thickness: $1.9 \pm 1.8 \mathrm{~mm})$, with one in three displaying some evidence of preparation such as overhang removal. The presence of numerous flakes smaller than $5 \mathrm{~mm}$ long indicates that at least some degree of manufacture took place on-site, a conclusion supported by the presence of a hammerstone. The few stone implements identified at Waredaru were generally larger than the mean length of flakes. Formal types

\begin{tabular}{|c|c|c|c|c|c|c|}
\hline \multirow{2}{*}{ Attribute } & \multicolumn{3}{|c|}{ Square A } & \multicolumn{3}{c|}{ Square B } \\
\cline { 2 - 7 } & Mean & Min. - Max. & $\#$ & Mean & Min. - Max. & $\#$ \\
\hline Weight $(\mathrm{g})$ & $30.3 \pm 4.1$ & $27.4-33.1$ & 2 & $0.6 \pm 0.3$ & $0.4-0.8$ & 2 \\
\hline Length $(\mathrm{mm})$ & $46.2 \pm 5.2$ & $42.5-49.8$ & 2 & $15.3 \pm 0.9$ & $14.6-15.9$ & 2 \\
\hline Width $(\mathrm{mm})$ & $37.0 \pm 5.5$ & $33.1-40.8$ & 2 & $11.3 \pm 2.5$ & $9.5-13.1$ & 2 \\
\hline Thickness $(\mathrm{mm})$ & $15.7 \pm 5.3$ & $11.9-19.4$ & 2 & $3.2 \pm 1.7$ & $2.0-4.4$ & 2 \\
\hline Elongation & $1.3 \pm 0.3$ & $1.0-1.5$ & 2 & $1.4 \pm 0.2$ & $1.2-1.5$ & 2 \\
\hline
\end{tabular}

Table 12 - Complete retouched chert flake dimensions and elongation.

Tableau 12 - Poids, dimensions et élongation des éclats retouchés. 
A
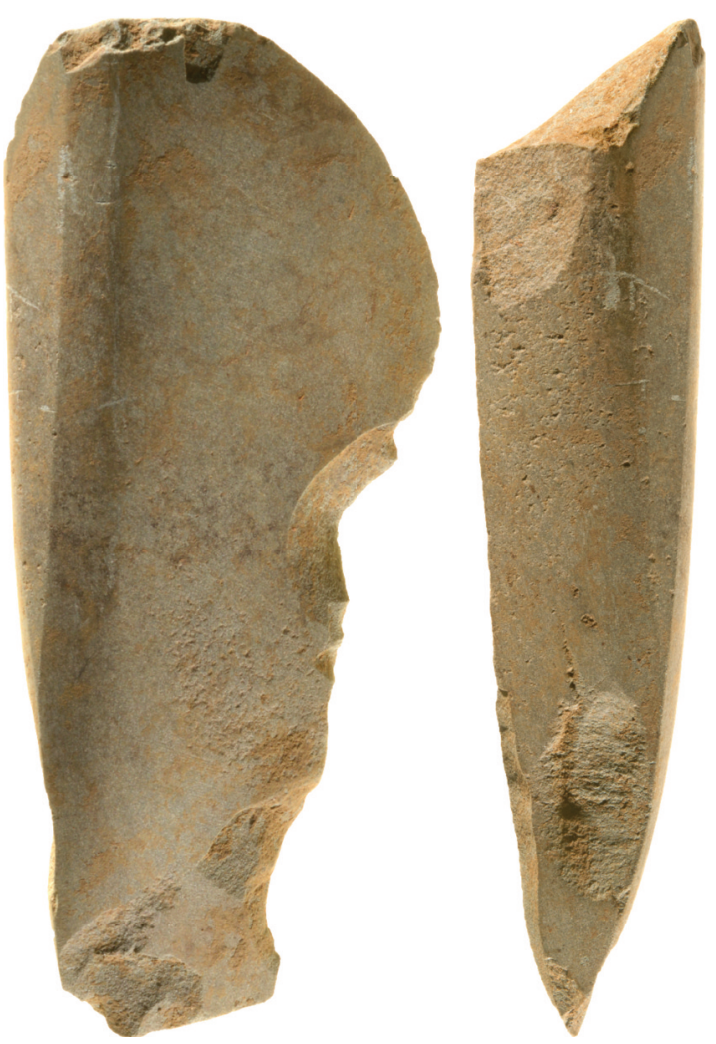

C

D
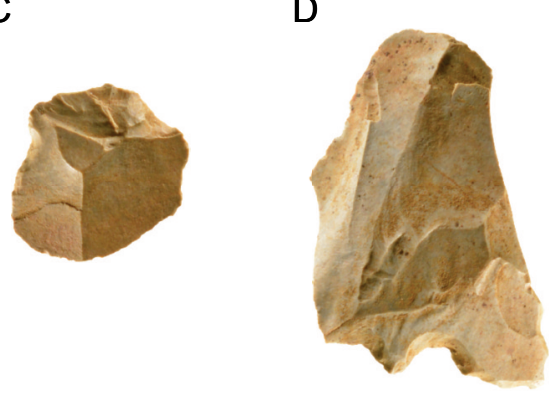

0

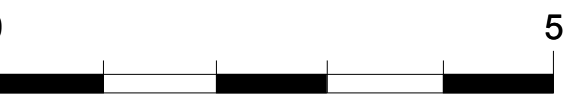

5

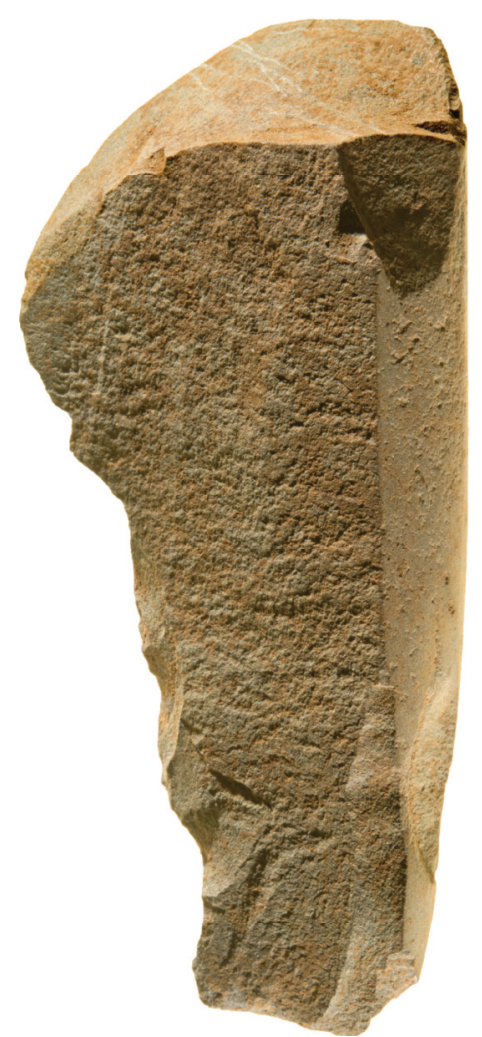

B

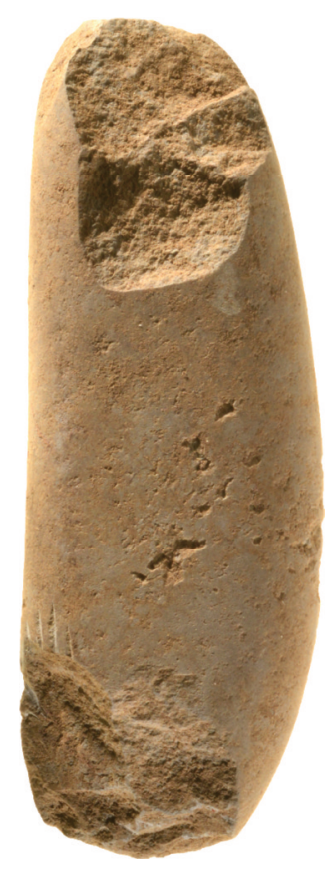

F

E
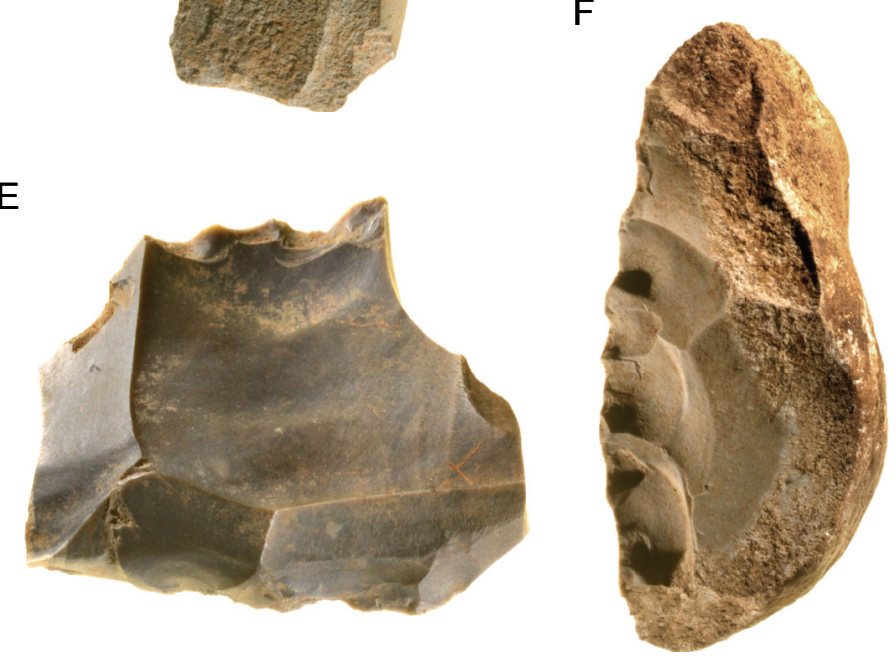

$\mathrm{cm}$

Figure 20 - Excavated stone tools from Waredaru. A: igneous axe/adze fragment; B: igneous hammerstone; C, D: possible sawaka notched tools; E: retouched flakes / flake-cores.

Figure 20 - L'outillage de Waredaru. A: Fragment de hache/herminette; B: Percuteur ignée; C, D: outils crantés de type sawaka; E, F: éclats retouchés / nuclei. 
include two notched tools, with less morphologically classifiable retouched chert flakes also being present as well as an igneous ground axe/adze fragment.

Overall, the Waredaru stone artefact assemblage is characterised by its highly fragmented state, including heat alteration. Chert reduction was performed on-site, although the first stage(s) of reduction (decortication flakes) was probably performed off-site (as evidenced by a paucity of flakes with large amounts of cortex at Waredaru). Chert reduction at Waredaru is intensive, possibly a result of the absence of suitable raw materials in the immediate vicinity of the site, although this explanation is not entirely satisfactory given its abundance within one hour of this village site, in areas that today form part of the same Keipte Kuyumen clan territory as Waredaru itself. Whether stone workers specifically journeyed to the sources to target chert nodules to bring back to Waredaru, or obtained them from those same sources more opportunistically while hunting or otherwise travelling the landscape, or scheduled activities with both quarrying and hunting in mind, during ethnographic times and during the period of oral traditions (including the period of occupation of Waredaru) chert nodules were readily available to Keipte Kuyumen clan members living at Waredaru. While the apparent absence of cores and the possible use of flake-cores at Waredaru suggest high levels of logistical mobility (Binford 1980), another, more likely interpretation relating to systematic sago-pounder manufacture presents itself, as also indicated by ethnography (see below). Under the logistical mobility model, since chert was not immediately available, small cores signal a highly portable and valuable part of a mobile tool-kit that stone workers can access when travelling to areas devoid of fine-grained siliceous materials. The recovery of an igneous axe/adze fragment of foreign raw material also suggests trade with Highlands groups.

The more enticing possibility of systematic sago-pounder manufacture is supported by the oral traditions that specifically mention Waredaru village as having engaged in such activities during occupation of the village. Ethnographically, the chert sources inland of the Keipte Kuyumen village of Waredaru produced widely renowned, high quality raw materials (tor and buri) for the making of sago stone pounders. These sago-pounders are shaped cores that were used locally, as well as traded southwards into lower-lying areas where fine-grained stone does not occur but where sago remains a major staple food, including for mass production for hiri trade (and therefore where demand for sago-pounders is high) (for details of hiri trade, see for example Allen 1977). The possibility that the bulk of the Waredaru lithic assemblage represents the byproducts of systematic sago-pounder manufacture counters interpretation of the Waredaru artefacts as evidence of curation strategies relating to logistical mobility and a multi-purpose, readily reducible and highly portable toolkit dominated by increasingly small cores. Rather, in the alternative and preferred (given the oral traditions) scenario, the Waredaru excavated artefacts relate to the specialised manufacture of sago-pounders for both local use and distant (especially downstream) trade, a feature of the village's history emphasised in the oral traditions as recounted by Wero Sisira, sago-pounders being essential for the processing of sago starch both locally and in more distant communities where stone was not available.

In 2007, 2008 and 2009, we visited numerous limestone outcrops in which chert nodules occur in large numbers, including Fakaiku and Tabakaroe quarries. At these quarries, early stages of nodule reduction were evident in small, discrete flaking areas indicating the removal of cortex on individual nodules. In 2008, members of the Keipte Kuyumen clan extracted numerous nodules from the limestone karst outcrops, bringing these back to the home base at Karupai (2.3 km northwest of Waredaru, also along the bank of Keip Creek). On this occasion, the individual nodules were extracted and transported back whole to the home base because Wero Sisira was ill and could not travel to the quarries, and therefore the quality of the nodules was not tested at the quarries, even though it was well known by all clan members that some nodules could contain thick chalky cortex entirely inappropriate for the manufacture of stone tools. Whether in older times nodules underwent initial reduction at the quarries to test for quality or for other reasons has not been addressed in ethnographic testimonies, but the presence of numerous flaking floors exhibiting decortication flakes at the quarries testifies to early-stage reduction at the source prior to transportation back to home villages. This is entirely consistent with the characteristics of the excavated stone artefacts at Waredaru as indicative of systematic later-stage reduction of specialised sago-pounders.

\section{Conclusion}

There is ample archaeological evidence at Waredaru for the existence of an ancient village. High quantities of fragmented burnt clay directly associated with pieces of charcoal and calcined animal bone indicate that at the time of the village, people cleaned out and discarded the claylined fireplaces of their stilt houses (as continues to be common practice today across the region; fig.13, 21). Charcoal from these discarded fireplaces were radiocarbon dated and showed that Waredaru village existed some 200 cal BP and lasted for some seven to 38 years. The dating of the village of Waredaru to ca. $200 \mathrm{cal} \mathrm{BP}$ indicates that the major ceremony of oral traditions undertaken within the village validating Keipte Kuyumen clan lands must date to that same period of time, indicating the beginning of the Keipte Kuyumen clan as a landed social unit in its own right. These archaeological results also indicate the segmentation of the larger ancestral Kuyumen clan some $200 \mathrm{cal}$ BP and the resilience of the Keipte Kuyumen clan as a social and territorial group for over 200 years.

The rich buried stone artefact deposits also strongly supports the knowledge from Keipte Kuyumen oral traditions that during its life, the village of Waredaru was a site of intensive stone working for the systematic manufacture of sago-pounders. 


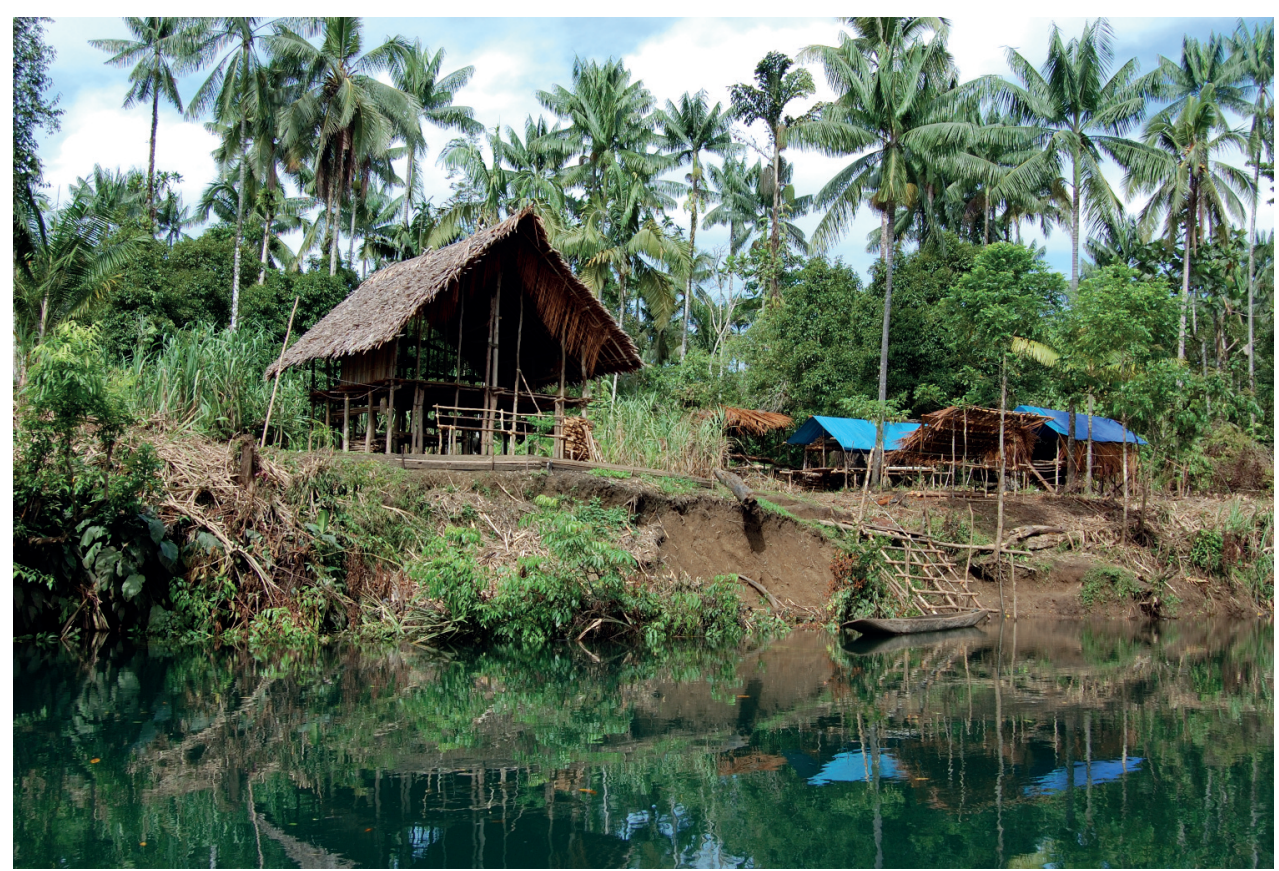

Figure 21 - Large Keipte Kuyumen stilt house, Karupai 2008 (photograph: Bruno David).

Figure 21 - Grande maison sur pilotis, Karupai 2008 (photographie : Bruno David).

Traces of earlier regional occupation in the form of small pieces of charcoal also occur sporadically in deeper levels, indicating the presence of people in the landscape ca. 1300 and 3000 cal BP. However, the few small pieces of buried charcoal are too sparse to indicate the presence of a village at those times.

\section{Acknowledgements}

We extend our deepest thanks to the members of the Keipte Kuyumen clan who welcomed us for this work, in particular clan leaders Wero Sisira, Mauke Omare and the late Kuto Sisira. Many thanks to Michael Mauke and Frank Wero and all community members for helping us understand Keipte Kuyumen clan lands, history and ancestors and for making us feel at home on their lands. Thanks to Nick Araho for helping with the excavations and Ursula Pietrzak and Nicole Pancer for undertaking the sediment analyses. BD thanks the Australian Research Council for Discovery grants, QEll and DORA Fellowships DP0877782 and DP130102514. Thanks to Jean-Georges Marcillaud for drawing Figure 4, Steve Morton for photographing the artefacts for Figures 32 and 33 and Kara Rasmanis for drafting the other Figures 1, 2, 11 and 13.

\section{Bibliography}

ALLEN J. 1977 - Sea traffic, trade and expanding horizons. In : J. Allen, J. Golson, and R. Jones (Eds), Sunda and Sahul: Prehistoric Studies in Island Southeast Asia, Melanesia and Australia, p. 387-417, Academic Press, London.
BINFORD L.R. 1980 - Willow smoke and dogs' tails: Hunter-gatherer settlement systems and archaeological site formation. American Antiquity, 45, p. 4-20.

BRONK-RAMSEY C. 2009 - Bayesian analysis of radiocarbon dates. Radiocarbon 51(1), p. 337-360.

BRONK-RAMSEY C. 2013 - OxCal Program v4.2, Radiocarbon Accelerator Unit, University of Oxford.

BURTON J. 1984 - Axe makers of the Wahgi: Pre-colonial industrialists of the Papua New Guinea Highlands. Canberra : Unpublished PhD thesis, Australian National University.

HISCOCK P. 2002 - Quantifying the size of artefact assemblages. Journal of Archaeological Science, 29, p. 251-258.

HISCOCK P. 2007 - Australian point and core reduction viewed through refitting. In $\mathrm{M}$. de Bie and U. Schurman (Eds), Fitting Rocks. Lithic refitting examined, British Archaeological Reports, International Monograph Series 1596, p. 105-118, Oxford: Archaeo Press.

HOPKINS M.S., ASH J., GRAHAM A.W., HEAD J. and HEWETT R.K. 1993 - Charcoal evidence of the spatial extent of the Eucalyptus woodland expansions and rainforest contractions in North Queensland during the late Pleistocene, Journal of Biogeography, 20, p. 357-372.

IRWIN G. 1985 - The Emergence of Mailu. Terra Australis 10. Research School of Pacific Studies, Australian National University, Canberra. 
MERCIECA A. 2000 - Burnt and broken: An experimental study of heat fracturing in silcrete. Australian Archaeology, 51 , p. $40-47$.

PAIJMANS K. and ROLLET B. 1977 - The mangroves of Galley Reach, Papua New Guinea. Forest Ecology and Management, 1, p. 119-140.

PETREQUIN P. and PETREQUIN A.-M. 2000 - Écologie d'un Outil: La Hache de Pierre en Irian Jaya (Indonésie). Monographie du CRA 12: CNRS Éditions, Paris.

REIMER P.J., BARD E., BAYLISS A., BECK J.W., BLACKWELL P.G., BRONK-RAMSEY C., BUCK C.E., CHENG H., EDWARDS R.L., FRIEDRICH M., GROOTES P.M., GUILDERSON T.P., HAFLIDASON H., HAJDAS I., HATTE C., HEATON T.J., HOGG A.G., HUGHEN K.A., KAISER K.F., KROMER B., MANNING S.W., NIU M., REIMER R.W., RICHARDS D.A., SCOTT E.M., SOUTHON J.R., TURNEY C.S.M. and VAN DER PLICHT J. 2013 IntCal13 and Marine13 radiocarbon age calibration curves 0 50,000 years cal BP, Radiocarbon, 55(4), p. 1869-1887. DOI: 10.2458/azu_js_rc.55.16947
RHOADS J.W. 1980 - Through a glass darkly: Present and past land-use systems of Papuan sagopalm users. Canberra : Unpublished PhD thesis, Australian National University.

RHOADS J.W. 2010 - Prehistoric Papuan axe/adzes: A spatial and temporal analysis of form. The Artefact, 33, p. 56-69.

RHOADS J.W. and MACKENZIE D.E. 1991 - Stone axe/adze trade in prehistoric Papua: The travels of Python. Proceedings of the Prehistoric Society, 57(2), p. 35-49.

UMBERGER E. 2002 - Imperial inscriptions in the Aztec landscape. In B. David and M. Wilson (Eds), Inscribed Landscapes : Marking and Making Place, p. 187-199, University of Hawaii Press, Honolulu. 
